\title{
A systematic review of methods to assess intake of fruits and vegetables among healthy European adults and children: a DEDIPAC (DEterminants of Dlet and Physical Activity) study
}

\author{
Fiona Riordan ${ }^{1, *}$, Kathleen Ryan ${ }^{2}$, Ivan J Perry ${ }^{1}$, Matthias B Schulze ${ }^{3}$, \\ Lene Frost Andersen ${ }^{4}$, Anouk Geelen ${ }^{5}$, Pieter van't Veer ${ }^{5}$, Simone Eussen ${ }^{6}$, \\ Pieter Dagnelie ${ }^{6}$, Nicole Wijckmans-Duysens ${ }^{6}$ and Janas $M$ Harrington ${ }^{1}$ \\ 'Department of Epidemiology and Public Health, University College Cork, Western Road, Cork, Republic of Ireland: \\ ${ }^{2}$ School of Applied Psychology, University College Cork, Cork, Republic of Ireland: ${ }^{3}$ Department of Molecular \\ Epidemiology, German Institute of Human Nutrition, Potsdam-Rehbrücke, Germany: ${ }^{4}$ Department of Nutrition, \\ Institute of Basic Medical Sciences, University of Oslo, Oslo, Norway: ${ }^{5}$ Division of Human Nutrition, Wageningen \\ University, Wageningen, The Netherlands: ${ }^{\circ}$ Department of Epidemiology of the Faculty of Health, Medicine and Life \\ Sciences, Maastricht University, Maastricht, The Netherlands
}

Submitted 24 September 2015: Final revision received 22 July 2016: Accepted 29 July 2016: First published online 14 September 2016

\begin{abstract}
Objective: Evidence suggests that health benefits are associated with consuming recommended amounts of fruits and vegetables (F\&V), yet standardised assessment methods to measure F\&V intake are lacking. The current review aims to identify methods to assess F\&V intake among children and adults in pan-European studies and inform the development of the DEDIPAC (DEterminants of DIet and Physical Activity) toolbox of methods suitable for use in future European studies.

Design: A literature search was conducted using three electronic databases and by hand-searching reference lists. English-language studies of any design which assessed F\&V intake were included in the review.

Setting: Studies involving two or more European countries were included in the review.

Subjects: Healthy, free-living children or adults.

Results: The review identified fifty-one pan-European studies which assessed F\&V intake. The FFQ was the most commonly used ( $n$ 42), followed by $24 \mathrm{~h}$ recall ( $n$ 11) and diet records/diet history $(n$ 7). Differences existed between the identified methods; for example, the number of F\&V items on the FFQ and whether potatoes/legumes were classified as vegetables. In total, eight validated instruments were identified which assessed F\&V intake among adults, adolescents or children.

Conclusions: The current review indicates that an agreed classification of F\&V is needed in order to standardise intake data more effectively between European countries. Validated methods used in pan-European populations encompassing a range of European regions were identified. These methods should be considered for use by future studies focused on evaluating intake of $F \& V$.
\end{abstract}

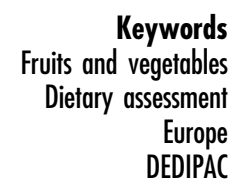

A poor diet is associated with four major noncommunicable diseases: cancer, CVD, diabetes and respiratory disorders ${ }^{(1-4)}$, which account for approximately $60 \%$ of deaths globally per annum ${ }^{(5)}$. There is a growing body of research which highlights the benefits of fruit and vegetable $(\mathrm{F} \& \mathrm{~V})$ consumption, including the protective effect of F\&V consumption on CVD ${ }^{(6,7)}$. The WHO Global Strategy on Diet and Physical Activity has made several key recommendations with respect to dietary intake, including increasing $\mathrm{F} \& \mathrm{~V}$ consumption ${ }^{(8)}$. In the 2004 joint report of the FAO/WHO Workshop on Fruit and Vegetables for Health, the WHO outlined a framework for developing interventions to promote adequate consumption of $F \& V$ in Member States ${ }^{(9)}$.

However, in order to develop and assess such interventions, and moreover to monitor the consumption of 
F\&V worldwide, reliable and comparable assessment methods are essential ${ }^{(10,11)}$. Methodological differences between studies which assess the intake of $F \& V$, including differences in the units of serving size and frequency, and the definition of what constitutes a fruit or vegetable, can often hinder meaningful comparisons ${ }^{(12)}$. As highlighted by Roark et $a l .{ }^{(12)}$, the definition of vegetables poses a particular problem. Debate focuses on whether legumes, pulses and/or potatoes are considered to be vegetables $^{(10,12)}$ and whether fruits should include nuts, olives and fruit juices which are $100 \%$ juice ${ }^{(10)}$. While F\&V can be defined by their nutritional content as 'low energydense foods, relatively high in vitamins, minerals, and other bioactive compounds as well as being a good source of fibre, (10) (p. 4), there is no agreed understanding of 'fruit' or 'vegetable' in terms of how they should be captured through dietary assessment methods; that is, what is considered a fruit or vegetable in one country may not be in another. This disparity may create issues when measuring and tracking intake across different regions ${ }^{(10)}$.

Previous and existing European projects have focused on the standardisation and harmonisation of food classification systems and food composition databases between countries (e.g. the International Food Data Systems Project, the Eurofoods initiative, the Food-Linked Agro-Industrial Research programme, COST Action 99, TRANSFAIR study, EUROFIR, etc.) ${ }^{(11,13-18)}$ and the IDAMES (Innovative Dietary Assessment Methods in Epidemiological Studies and Public Health) project has evaluated new-generation methods to assess dietary intake in Europe ${ }^{(19)}$, developing the European Food Propensity Questionnaire for use within European countries. Guidelines from the European Food Safety Authority recommend the use of a computerised method (e.g. EPIC-SOFT or similar) for collection of accurate, standardised, food consumption data at the European level $^{(20,21)}$. However, standards have not, as yet, been developed for the assessment of dietary intake, including intake of $F \& V$, as part of aetiological studies. Thematic Area 1 of the DEDIPAC (DEterminants of DIet and Physical Activity) project ${ }^{(22)}$ aims to address this gap and add to our understanding of the most effective, harmonised methods of dietary intake assessment by preparing a toolkit of the most useful measurement tools of dietary intake that can be used extensively across Europe ${ }^{(22,23)}$. The aim of the current systematic literature review was to identify suitable assessment methods that may potentially be used to measure intake of $\mathrm{F} \& \mathrm{~V}$ in European children and adults in pan-European studies.

\section{Materials and methods}

\section{Data sources and study selection}

The current review adheres to the guidelines of the PRISMA (Preferred Reporting Items for Systematic Reviews and Meta-Analyses) Statement. The protocol for the review can be accessed from PROSPERO (CRD42014012947) ${ }^{(24)}$. A systematic literature search for pan-European studies that assessed the intake of F\&V was conducted. For this review, we used the definition of $F \& V$ proposed by Agudo $^{(10)}$ : 'vegetables and foods used as vegetables', with fruits taken to be fresh or preserved fruits. Our definition included nuts, legumes and potatoes, and only $100 \%$ fruit juice was considered a fruit. Legumes and potatoes are not consistently included as vegetables across dietary assessment methods; therefore, where possible, it was reported whether the instrument in question excluded or included these items as vegetables. Two authors, F.R. and K.R., independently conducted a search of PubMed, EMBASE and Web of Science databases, using combinations of the following search terms: 'fruit/s' and 'vegetable/s', with keywords for dietary intake, including 'diet', 'eating', 'consumption', 'intake', and search terms for European countries. A full copy of the EMBASE search strategy is presented in the online supplementary material, Supplemental Table 1. All searches were limited to English-language literature published from 1990 through to 7 July 2014.

Titles and abstracts of the sourced articles were independently screened by F.R. and K.R. If in doubt regarding inclusion, the article was retained for full-text review. Any disagreement during the full-text review stage was resolved through consultation with a third author, J.M.H. Studies were included if they assessed the intake of $\mathrm{F} \& \mathrm{~V}$ within two or more European countries, as defined by the Council of Europe ${ }^{(25)}$. Participants were required to be free-living, healthy populations of any age; therefore we excluded hospital-based populations and studies which focused on a specific disease subgroup (e.g. diabetic cohort) or any fixed societal subgroups (e.g. pregnant women). The review was not limited to certain study designs. If studies compared two groups, one of which was a healthy general population, they were included. Intervention studies were eligible if F\&V intake was measured at baseline before any dietary intervention was undertaken. Similarly, case-control studies were included if intake was assessed in populationbased controls. Studies were included only if they assessed intake of F\&V at the level of the individual; that is, those which assessed household-level consumption of F\&V were excluded (Fig. 1).

Reference lists of all included papers, along with relevant meta-analysis and literature reviews, were reviewed for further publications not identified by the original search. Databases were also searched using the names of individual European projects listed in the DEDIPAC Inventory of Relevant European Studies, a compilation which is an ongoing part of DEDIPAC. Authors were contacted to obtain full versions of the relevant instruments or questionnaires and some articles; and the Endnote library of a concurrently occurring systematic literature review on methods to assess intake of sugarsweetened beverages was reviewed for further studies. 


\section{Data extraction and quality assessment}

Data extraction was carried out using a form that was developed, piloted and subsequently revised to capture the following data: study design; number and names of European countries involved; sample size (total and number for each country); age range of the included population; the method used and description (including frequency categories for FFQ, number of items/items that referred to $\mathrm{F} \& \mathrm{~V}$, details of portion estimation); mode of administration; and details on the validation or reproducibility. Originally sourced articles which described the assessment methods in the most detail were selected for inclusion in the review, with further information on the methods obtained from articles sourced from reference lists. One reviewer extracted the data for each study, which was confirmed by the other reviewer.

The aim of the current systematic literature review was to identify and describe assessment methods that have been used to assess intake of F\&V. Therefore, a comprehensive quality appraisal of each included article was not conducted as part of the current review. However, it was recorded whether or not the instrument in question had been tested for validity and/or reproducibility, and relevant validation studies were referenced where possible. Data were extracted from these studies by P.D., S.E. and N.W.-D. to inform the instrument selection. In order to determine which instruments would be appropriate to use in pan-European studies, two selection criteria were applied: (i) the instrument was reviewed for validity and/or reproducibility, of which a summary of its indicators is presented; and (ii) the instrument was used in more than two countries simultaneously that represented a range of European regions. A 'range' meant that at least one country from at least three of the Southern, Northern, Eastern and Western European regions, as defined by the United Nations, were included ${ }^{(26)}$. The results of this selection are shown in Table 1 .

\section{Results}

\section{Description of the included studies}

As shown in Fig. 1, 5678 papers remained once duplicates were removed, and 167 were retained after screening titles and abstracts and following full-text screening.

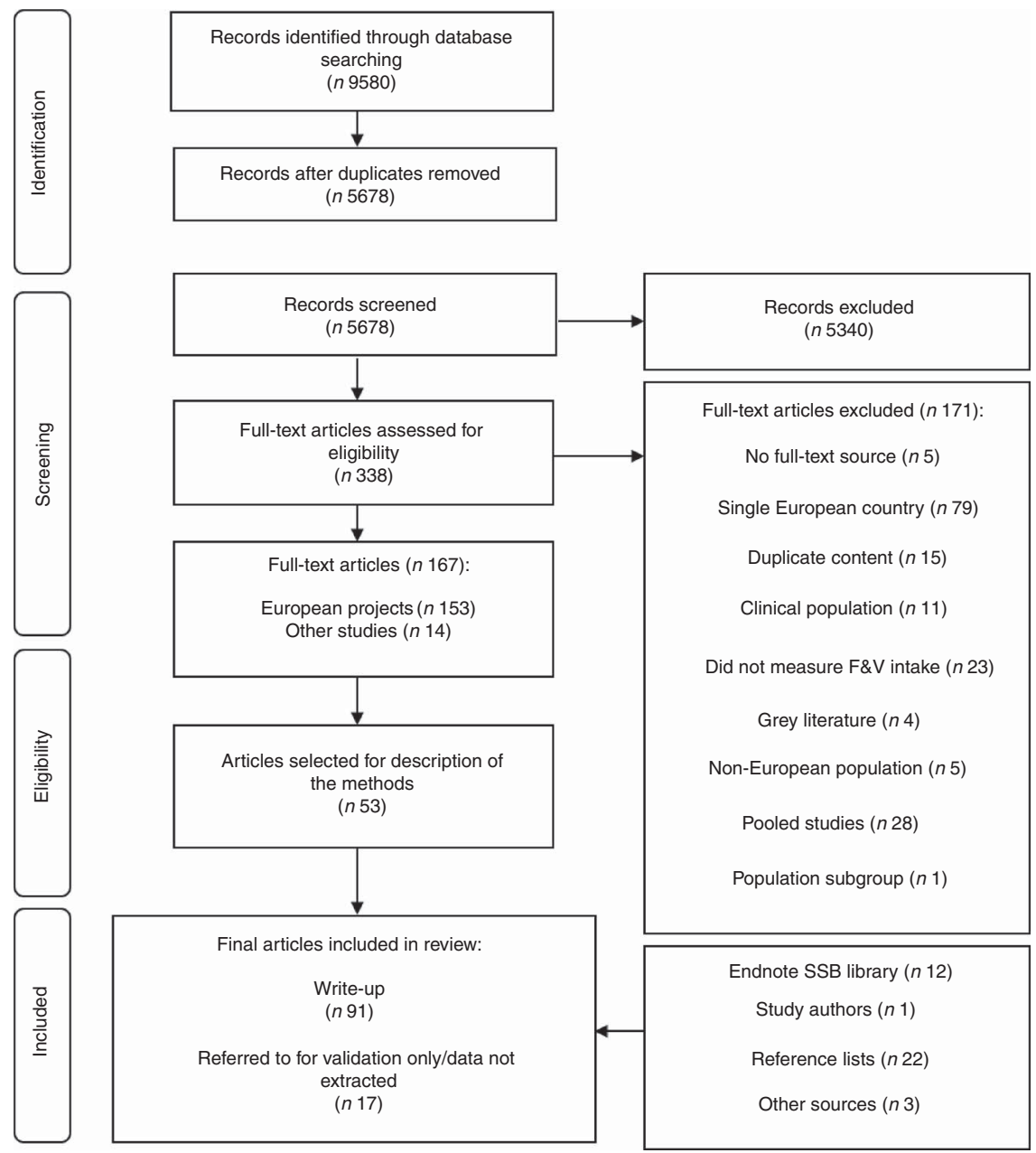

Fig. 1 Flow diagram showing study selection process for the current review (F\&V, fruit and vegetable; SSB, sugar-sweetened beverages) 
These articles were grouped according to the major European project to which they belonged ( $n$ 153) or grouped as 'Other' ( $n$ 14) if they did not belong to a project. From these 167 articles, fifty-three articles were selected, typically one to three articles per project, which best described the background to the project or the methods used (Fig. 1).

Reviewing the reference lists yielded twenty-two further articles in which the methods were described ${ }^{(18,27-47)}$. Twelve further articles were obtained from the Endnote library on sugar-sweetened beverages in which two additional studies assessing the intake of F\&V, the ToyBox study and a study by Kolarzyk et al. ${ }^{(48)}$, were described. One article was obtained from authors ${ }^{(49)}$. Unpublished details on the instruments used as part of the I.Family Project $^{(50)}$, the IDEFICS (Identification and prevention of Dietary- and lifestyle-induced health EFfects In Children and infants) study follow-up, were obtained through contact with the IDEFICS group. Articles on the background and validation of the Food4Me project, published after the search dates, were also added to the review ${ }^{(51-53)}$. The term 'study' is used in the current review to refer to the larger project, rather than individual analyses/ publications that may arise from the same project, and therefore use the same methodology.

Taking together the articles sourced and selected from our original search ( $n$ 53), from reference lists ( $n$ 22), from the concurrent review on sugar-sweetened beverages ( $n$ 12), from authors ( $n$ 1) and articles added subsequently ( $n$ 3), a total of ninety-one articles covering fifty-one studies were included in the review. For each of the methods identified, article(s) which described the validation or reliability testing performed for that method were recorded. As a result, seventeen further articles were sourced in which validation and/or reliability testing for the identified methods was described. The characteristics of the included studies $^{(4,18,27-48,50-145)}$ are described in Table 2.

From the sourced articles, fifty-one pan-European studies in total were identified: thirty-five named projects and sixteen smaller projects $^{(48,54,56,65,69,72,82,83,88,93,94,107,109,113,114,116)}$. Most studies assessed dietary intake of $F \& V$ among adults $(18,41,44,46,48,50,51,54-57,59,60,64-66,68,69,71,72,75-79,81-84,86,88$, 92-94,107,146,147)

Five assessed parents or caregivers $^{(27,50,85-87,102)}$. Four studies examined intake among older adults, namely MEDIS (MEDiterranean Islands Study $)^{(78)}$, the Seven Countries Study ${ }^{(4,91,92)}$, SENECA (Survey in Europe on Nutrition and the Elderly; a Concerted Action) $)^{(43,90,148,149)}$ and the 'Food in later life' study ${ }^{(68)}$. Nine studies assessed intake among chil$\operatorname{dren}^{(27,30,37,50,85,86,101,116,120)}$ in age ranges 2-9 years ${ }^{(37,118,119)}$, 3-6 years ${ }^{(95-106)}, 2-11$ years $^{(50)}, 7-11$ years $^{(116)}, 11$ years ${ }^{(85)}$ and 10-12 years ${ }^{(27)}$, and seven assessed intake among adolescents $^{(32,50,109,110,113-115)}$.

\section{Validation}

Table 2 provides detail on the instruments' validation. Of the studies which were validated or tested for reproducibility and fulfilled inclusion criterion 1 (Table 1 ), validity and reliability of the FFQ was assessed using biomarkers $^{(63,126)}$ FFQ $^{(52)}$, food records ${ }^{(42,53,80,128-132,137,138)}$ or $24 \mathrm{~h}$ recalls $(24-\mathrm{HDR})^{(36,38,80,129,135)}$ as the reference method. In fifteen studies, validity was assessed by crude correlations $^{(35,36,38,42,53,63,80,126,128,130,132,137,138)}$, energyadjusted correlations ${ }^{(52,53,126,129)}$, de-attenuated correlation coefficients ${ }^{(36,38,129,137)}$, mean or median differences in $\mathrm{F} \& \mathrm{~V}$ consumption $(35,36,38,42,52,53,80,126,128-130,132,137,138)$, exact level of agreement of F\&V consumption $^{(38,42,52,53,80,126,130,132,137,138)}$, Bland-Altman plots ${ }^{(36,52,53,129)}$ or weighted kappa ${ }^{(38,137)}$ between the FFQ and reference instrument. In nine studies, reliability of F\&V consumption was assessed by correlations ${ }^{(36,42,53,80,131,132,137,145)}$, mean/median differences ${ }^{(36,80,137,138,145)}$, weighted kappa $^{(132,138,145)}$ or intraclass correlation coefficients ${ }^{(137)}$ between subsequent assessments of the FFQ. Where available, data were extracted and are provided in detail in the online supplementary material, Supplemental Table 2.

\section{Dietary intake assessment methods}

Types of methods

Several methods were used to assess dietary intake of $F \& V$ in the identified studies. The vast majority of the pan-European studies used FFQ $\left(\begin{array}{ll}n & 42\end{array}\right)^{(27,29,30,36,41 \text {, }}$ 48,50,52,54-56,58-60,64-66,69,71,72,75,76,78,79,82,84-86,88,93,104,109,110, $113-116,120,139,146,150)$. Since a common FFQ instrument was not used across all countries in the EPIC (European Prospective Investigation into Cancer and Nutrition) study, only the EPIC-SOFT instrument is discussed in the current review.

According to the two selection criteria (i.e. whether tested for validity or reproducibility and used in more than two countries representing a range of European regions; Table 1), six instruments were appropriate to assess intake of $\mathrm{F} \& \mathrm{~V}$ in future pan-European studies among adults: EPIC-SOFT, the Food4Me FFQ, the ToyBox Primary Caregiver's Questionnaire, the ENERGY (EuropeaN Energy balance Research to prevent excessive weight Gain among Youth) parent questionnaire, and the dietary history methods used by the SENECA study and Seven Countries Study. Three instruments used to assess intake among adolescents, HELENA-DIAT (Healthy Lifestyle in Europe by Nutrition in Adolescence-Dietary Assessment Tool), HELENA online FFQ and the HBSC (Health Behaviour in School-aged Children) FFQ, fulfilled the criteria. The ENERGY children's questionnaire and the instruments used by the IDEFICS, Pro-Children and ToyBox studies appeared appropriate to measure F\&V among children. Although not validated separately, the I.Family instruments were based closely on those of the IDEFICS study and also met the criteria. The 24-HDR preceded by the $1 \mathrm{~d}$ qualitative food record used in the EYHS (European Youth Heart Study) was a validated method but not tested in the study population $^{(144)}$. While Table 1 indicates the selected 
Table 1 Identified instruments according to criteria. Instruments which meet both criteria are shaded

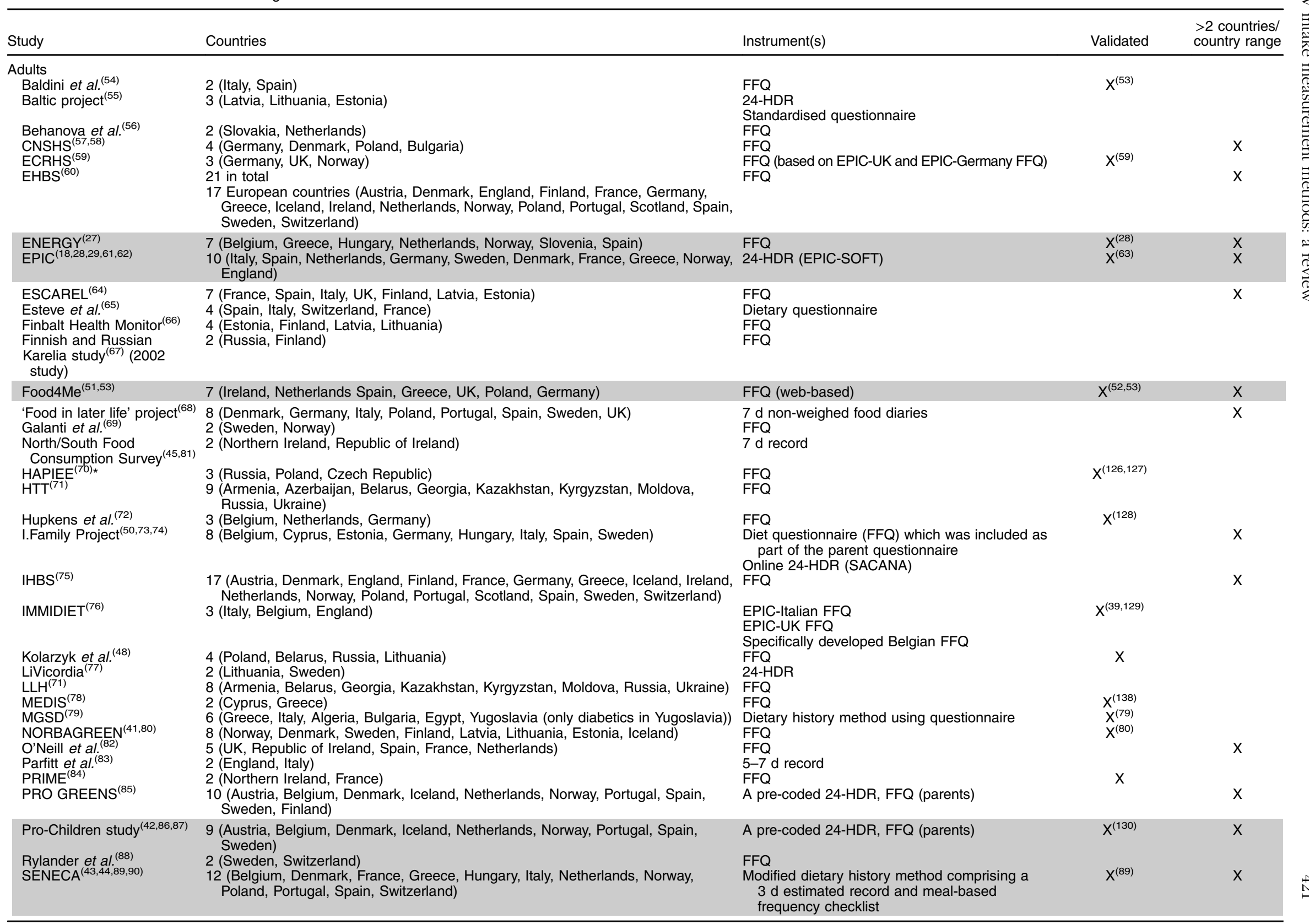




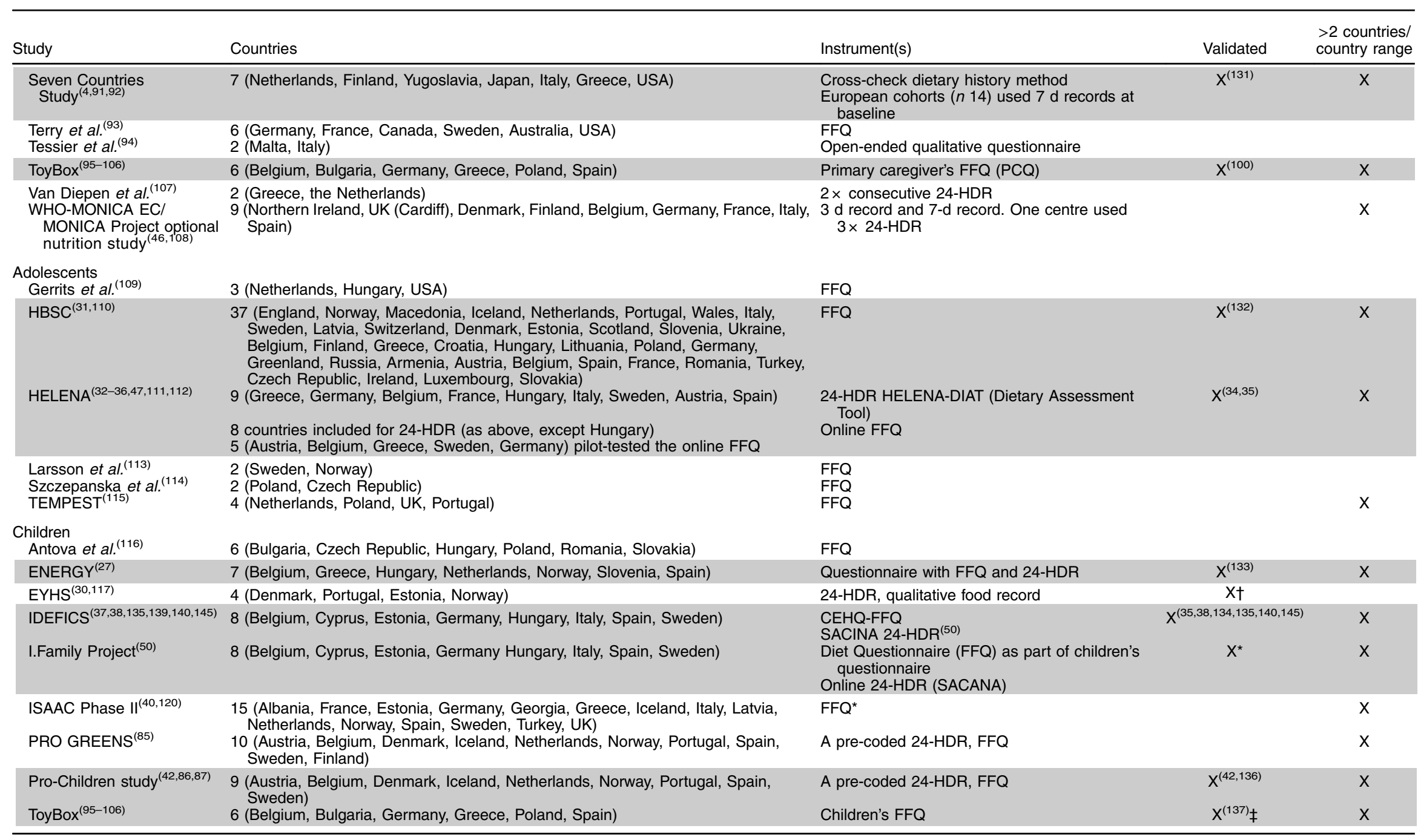

CNSHS, Cross National Student Health Survey; ECRHS, European Community Respiratory Health Survey; EHBS, European Health and Behaviour Survey; ENERGY, EuropeaN Energy balance Research to prevent excessive weight Gain among Youth; EPIC, European Prospective Investigation into Cancer and Nutrition; ESCAREL, European Study in Non Carious Cervical Lesions; HAPIEE, Health, Alcohol and Psychosocial factors in Eastern Europe; HTT, Health in Times of Transition; IHBS, International Health and Behaviour Survey; LLH, Living Conditions, Lifestyles and Health; MEDIS, MEDiterranean Islands Study; MGSD, Mediterranean Group for the Study of Diabetes; PRIME, Prospective Epidemiological Study of Myocardial Infarction; SENECA, Survey in Europe on Nutrition and the Elderly; a Concerted Action; MONICA, Multinational MONItoring of trends and determinants in CArdiovascular disease, HBSC, Health Behaviour in School-aged Children, HELENA, Healthy Lifestyle in Europe by Nutrition in Adolescence; TEMPEST, 'Templations to Eat Moderated by Personal and Environmental Self-regulatory Tools'; EYHS, European Youth Heart Study; IDEFICS, Identification and prevention of Dietary- and lifestyle-induced health EFfects In Children and infantS; ISAAC, International Study of Asthma and Allergies in Childhood; 24-HDR, 24 h recall; PCQ, Primary Caregiver's Questionnaire; CEHQ, Children's Eating Habits Questionnaire.

*Based on the IDEFICS instruments which were validated.

.

†The reliability study on the FFQ is unpublished. 


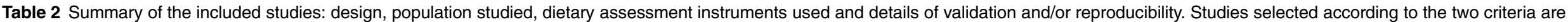
shaded. Where validation or reliability data was not available for fruit and vegetables specifically, this is highlighted in bold font

\begin{tabular}{|c|c|c|c|c|c|c|}
\hline Study & Design & Population & Countries & Instrument(s) & Validation & Reproducibility \\
\hline \multicolumn{7}{|l|}{ Adults } \\
\hline Baldini et al. ${ }^{(54)}$ & Cross-sectional & $\begin{array}{l}\text { Adults/students ( } n \text { 210) } \\
\text { Age range NR }\end{array}$ & 2 (Italy, Spain) & FFQ & $\begin{array}{l}\text { Based on the Willett FFQ } \\
\text { Validated against diet records }{ }^{(124)} \\
\text { No validation data for F\&V }\end{array}$ & No details $\ddagger$ \\
\hline Baltic project ${ }^{(55)}$ & Cross-sectional & $\begin{array}{l}\text { Adults }(n 4571) \\
19-65 \text { years }\end{array}$ & 3 (Latvia, Lithuania, Estonia) & $\begin{array}{l}\text { 24-HDR } \\
\text { Standardised } \\
\quad \text { questionnaire }\end{array}$ & No details $\ddagger$ & No detailsł \\
\hline Behanova et al. ${ }^{(56)}$ & Cross-sectional & $\begin{array}{l}\text { Adults }(n 210) \\
19-64 \text { years }\end{array}$ & 2 (Slovakia, Netherlands) & FFQ† & No details $\ddagger$ & No details $\ddagger$ \\
\hline $\mathrm{CNSHS}^{(57,58)}$ & Cross-sectional & $\begin{array}{l}\text { Adults/students } \\
(n 2651) \\
\text { Age range NR }\end{array}$ & $\begin{array}{l}4 \text { (Germany, Denmark, } \\
\text { Poland, Bulgaria) }\end{array}$ & FFQ & $\begin{array}{l}\text { No test of validity was performed, but } \\
\text { the questionnaire was similar to other } \\
\text { FFQ that have been validated }\end{array}$ & \\
\hline $\mathrm{ECRHS}^{(59)}$ & Cross-sectional & $\begin{array}{l}\text { Adults }(n 1174) \\
30-70 \text { years }\end{array}$ & 3 (Germany, UK, Norway) & $\begin{array}{l}\text { FFQ (based on EPIC-UK } \\
\text { and EPIC-Germany } \\
\text { FFQ) }\end{array}$ & $\begin{array}{l}\text { German and UK FFQ validated against } \\
24-\mathrm{HDR}^{(125,141)} \\
\text { The Norwegian FFQ was not assessed } \\
\text { for repeatability or validity }\end{array}$ & $\begin{array}{l}\text { Reproducibility of German FFQ } \\
\text { obtained by a repeated administration } \\
\text { of the FFQ at a } 6 \text {-month interval }{ }^{(125)} \text {. } \\
\text { Repeatability of the UK FFQ using } \\
\text { two assessments separated by an } \\
\text { interval of } 5-23 \text { months }{ }^{(59)}\end{array}$ \\
\hline EHBS $^{(60)}$ & Cross-sectional & $\begin{array}{l}\text { Adults/students } \\
\quad(n 7115) \\
17-30 \text { years }\end{array}$ & $\begin{array}{l}21 \text { in total } \\
17 \text { European countries } \\
\text { (Austria, Denmark, } \\
\text { England, Finland, France, } \\
\text { Germany, Greece, Iceland, } \\
\text { Ireland, Netherlands, } \\
\text { Norway, Poland, Portugal, } \\
\text { Scotland, Spain, Sweden, } \\
\text { Switzerland) }\end{array}$ & FFQ $\dagger$ & No details $\ddagger$ & $\begin{array}{l}\text { Reliability of the measures are } \\
\text { described }{ }^{(142)} \text { but no reliability data } \\
\text { on F\&V }\end{array}$ \\
\hline ENERGY(27) & Cross-sectional & $\begin{array}{l}\text { Adults/parents or } \\
\text { guardians }(n 6002) \\
\text { Age range NR }\end{array}$ & $\begin{array}{l}7 \text { (Belgium, Greece, } \\
\text { Hungary, Netherlands, } \\
\text { Norway, Slovenia, Spain) }\end{array}$ & FFQ† & No details $\ddagger$ & $\begin{array}{l}\text { The reliability and content validity of the } \\
\text { parent questionnaires were tested } \\
\text { separately in all participating } \\
\text { countries, in five schools per country } \\
\text { using approximately fifty parents per } \\
\text { country for the reliability study and } \\
\text { twenty parents for the construct } \\
\text { validity study (unpublished results) }\end{array}$ \\
\hline $\operatorname{EPIC}^{(18,28,29,61-63)}$ & Cohort & $\begin{array}{l}\text { Adults ( } n 519978 \text { ) } \\
30-70 \text { years }\end{array}$ & $\begin{array}{l}10 \text { (Italy, Spain, Netherlands, } \\
\text { Germany, Sweden } \\
\text { (Malmo)/Sweden (Umea), } \\
\text { Denmark, France, Greece, } \\
\text { Norway, England) }\end{array}$ & $\begin{array}{l}\text { FFQ†, 24-HDR (EPIC- } \\
\text { SOFT) }\end{array}$ & $\begin{array}{l}\text { EPIC-SOFT was validated against } \\
\text { biomarkers for F\&V consumption } \\
\text { Assessed by crude correlations } \\
\text { Weak to moderate association between } \\
\text { biomarkers and F\&V intake }\end{array}$ & No details $\ddagger$ \\
\hline ESCAREL $^{(64)}$ & Cross-sectional & $\begin{array}{l}\text { Adults }(n 3187) \\
18-35 \text { years }\end{array}$ & $\begin{array}{c}7 \text { (France, Spain, Italy, UK, } \\
\text { Finland, Latvia, Estonia) }\end{array}$ & FFQ† & $\begin{array}{l}\text { Bartlett et al. }{ }^{(64)} \text { report that all } \\
\text { questionnaires were validated in pilot } \\
\text { studies } \\
\text { No reference or data available }\end{array}$ & \\
\hline Esteve et al. ${ }^{(65)}$ & Case-control & $\begin{array}{l}\text { Adults/controls } \\
(n 3057) \\
\text { Age range NR }\end{array}$ & $\begin{array}{l}4 \text { (Spain, Italy, Switzerland, } \\
\text { France) }\end{array}$ & Dietary questionnaire & No details $\ddagger$ & No details $\ddagger$ \\
\hline Finbalt Health Monitor ${ }^{(66)}$ & Cross-sectional & $\begin{array}{l}\text { Adults }(n 25044) \\
20-64 \text { years }\end{array}$ & $\begin{array}{l}4 \text { (Estonia, Finland, Latvia, } \\
\text { Lithuania) }\end{array}$ & FFQ† & No details $\ddagger$ & No details $\ddagger$ \\
\hline
\end{tabular}


Table 2 Continued

\begin{tabular}{|c|c|c|c|c|c|c|}
\hline Study & Design & Population & Countries & Instrument(s) & Validation & Reproducibility \\
\hline $\begin{array}{l}\text { Finnish and Russian Karelia } \\
\text { study }^{(67)}(2002 \text { study) }\end{array}$ & Cross-sectional & $\begin{array}{l}\text { Adults }(n 1201) \\
25-64 \text { years }\end{array}$ & 2 (Russia, Finland) & FFQ† & No detailsł & No details $\ddagger$ \\
\hline 'Food in later life project'(68) & Cross-sectional & $\begin{array}{l}\text { Adults }(n 644) \\
65-98 \text { years }\end{array}$ & $\begin{array}{l}8 \text { (Denmark, Germany, Italy, } \\
\text { Poland, Portugal, Spain, } \\
\text { Sweden, UK) }\end{array}$ & $\begin{array}{l}7 \text { d non-weighed food } \\
\text { diaries }\end{array}$ & No detailsł & No details $\ddagger$ \\
\hline Food4Me $\mathrm{e}^{(51-53)}$ & $\begin{array}{l}\text { Randomised } \\
\text { controlled trial }\end{array}$ & $\begin{array}{l}\text { Adults }(n 5562) \\
17-79 \text { years }\end{array}$ & $\begin{array}{l}7 \text { (Ireland, Netherlands, } \\
\text { Spain, Greece, UK, } \\
\text { Poland, Germany) }\end{array}$ & FFQ (web-based) & $\begin{array}{l}\text { Validated against } 4 \mathrm{~d} \text { non-consecutive } \\
\text { weighed records }{ }^{(53)} \text { and by } \\
\text { comparing with the validated EPIC- } \\
\text { Norfolk FFQ }{ }^{(52)} \\
\text { Assessed by crude correlations, energy- } \\
\text { adjusted correlations, and mean or } \\
\text { median differences in F\&V } \\
\text { consumption } \\
\text { Moderate agreement with } 4 \mathrm{~d} \text { weighed } \\
\text { food record }\end{array}$ & $\begin{array}{l}\text { Interval: } 4 \text { weeks }{ }^{(53)} \\
\text { Assessed by correlations } \\
\text { Reproducible for nutrient and food group } \\
\text { intake }\end{array}$ \\
\hline Galanti et al. ${ }^{(69)}$ & Cross-sectional & Adults ( $n$ 440) & 2 (Sweden, Norway) & FFQ† & No detailsł & No details $\ddagger$ \\
\hline $\operatorname{HAPIEE}^{(70) *}$ & Cross-sectional & Adults ( $n$ 28 947) & $\begin{array}{l}3 \text { (Russia, Poland, Czech } \\
\text { Republic) }\end{array}$ & FFQ† & $\begin{array}{l}\text { Based on the Whitehall II questionnaire. } \\
\text { Validated against a } 7 \mathrm{~d} \text { diet diary and } \\
\text { biomarkers of nutrient intake by } \\
\text { Brunner et al. }{ }^{(126)} \text {. Whitehall II } \\
\text { questionnaire was originally } \\
\text { developed by Willett et al. }{ }^{(27)} \\
\text { Assessed by energy-adjusted } \\
\text { correlations, mean or median } \\
\text { differences, and exact level of } \\
\text { agreement. Good correlation of } \\
\text { intakes estimated by FFQ with } \\
\text { biomarkers } \\
\text { Overestimation of vitamin C and } \\
\text { carotenes by FFQ relative to } 7 \mathrm{~d} \text { diet } \\
\text { diary }\end{array}$ & No details $\ddagger$ \\
\hline $\mathrm{HTT}^{(71)}$ & Cross-sectional & Adults ( $n$ 18 000) & $\begin{array}{l}9 \text { (Armenia, Azerbaijan, } \\
\text { Belarus, Georgia, } \\
\text { Kazakhstan, Kyrgyzstan, } \\
\text { Moldova, Russia, Ukraine) }\end{array}$ & FFQ† & No details $\ddagger$ & No details $\ddagger$ \\
\hline Hupkens et al. ${ }^{(72)}$ & Cross-sectional & Adults/women ( $n$ 849) & $\begin{array}{l}3 \text { (Belgium, Netherlands, } \\
\text { Germany) }\end{array}$ & $\begin{array}{l}\text { FFQ† } \\
\text { (based on Netherlands } \\
\text { Cohort Study FFQ) }\end{array}$ & $\begin{array}{l}\text { Validated using diet records }{ }^{(128)} \\
\text { Assessed by crude correlations, mean } \\
\text { or median differences } \\
\text { FFQ can rank individuals according to } \\
\text { food groups and nutrient intake }\end{array}$ & No details $\ddagger$ \\
\hline I.Family Project ${ }^{(50,73,74)}$ & $\begin{array}{l}\text { Prospective } \\
\text { cohort study } \\
\text { (successor of } \\
\text { IDEFICS study) }\end{array}$ & $\begin{array}{l}\text { Adults/parents } \\
\quad(n>7000)\end{array}$ & $\begin{array}{l}8 \text { (Belgium, Cyprus, Estonia, } \\
\text { Germany Hungary, Italy, } \\
\text { Spain, Sweden) }\end{array}$ & $\begin{array}{l}\text { Diet questionnaire as part } \\
\text { of the parent } \\
\text { questionnaire } \\
\text { Online 24-HDR } \\
\text { (SACANA) }\end{array}$ & $\begin{array}{l}\text { Similar to validated instruments used in } \\
\text { the IDEFICS project }\end{array}$ & No details $\ddagger$ \\
\hline IHBS $^{(75)}$ & Cross-national & Adults ( $n$ 17246) & $\begin{array}{l}17 \text { (Austria, Denmark, } \\
\text { England, Finland, France, } \\
\text { Germany, Greece, Iceland, } \\
\text { Ireland, Netherlands, } \\
\text { Norway, Poland, Portugal, } \\
\text { Scotland, Spain, Sweden, } \\
\text { Switzerland) }\end{array}$ & FFQ† & No details $\ddagger$ & No details $\ddagger$ \\
\hline
\end{tabular}


Table 2 Continued

\begin{tabular}{|c|c|c|c|c|c|c|}
\hline Study & Design & Population & Countries & Instrument(s) & Validation & Reproducibility \\
\hline IMMIDIET $^{(76)}$ & Cross-sectional & Adults ( $n$ 802) & 3 (Italy, Belgium, England) & $\begin{array}{l}\text { EPIC-Italian FFQ† } \\
\text { EPIC-UK FFQ† } \\
\text { Specifically developed } \\
\text { Belgian FFQ }\end{array}$ & $\begin{array}{l}\text { Based on EPIC UK and Italian FFQ } \\
\text { which have been validated using } \\
\text { weighed diet records } \\
\text { biomarkers }^{(141)} \text { (14143) and } 24-\mathrm{HDR}^{(143)} \\
\text { Belgian FFQ validated using } 7 \text { d diet } \\
\text { records and } 24-\mathrm{HDR}^{(39,129)} \\
\text { Assessed by energy-adjusted } \\
\text { correlations, de-attenuated } \\
\text { correlation coefficients, and mean or } \\
\text { median differences } \\
\text { Generally good correlation between } \\
\text { FFQ and diet records }\end{array}$ & No detailsł \\
\hline Kolarzyk et al. ${ }^{(48)}$ & Cross-sectional & $\begin{array}{l}\text { Adults/students } \\
\quad(n \text { 1517) }\end{array}$ & $\begin{array}{l}4 \text { (Poland, Belarus, Russia, } \\
\text { Lithuania) }\end{array}$ & FFQ† & $\begin{array}{l}\text { Validated and recommended by the } \\
\text { National Food and Nutrition Institute } \\
\text { in Warsaw, Poland } \\
\end{array}$ & No details $\ddagger$ \\
\hline LiVicordia $^{(77)}$ & Cross-sectional & Adults/men (n 150) & 2 (Lithuania, Sweden) & 24-HDR & No details $\ddagger$ & No details $\ddagger$ \\
\hline $\mathrm{LLH}^{(71)}$ & Cross-sectional & Adults (n 18428 ) & $\begin{array}{l}8 \text { (Armenia, Belarus, } \\
\text { Georgia, Kazakhstan, } \\
\text { Kyrgyzstan, Moldova, } \\
\text { Russia, Ukraine) }\end{array}$ & $\mathrm{FFQ}$ & No details $\ddagger$ & No details $\ddagger$ \\
\hline $\operatorname{MEDIS}^{(78)}$ & Cross-sectional & Adults/elderly ( $n$ 1190) & 2 (Cyprus, Greece) & $\mathrm{FFQ}$ & $\begin{array}{l}\text { Validated using diet records }{ }^{(138)} \\
\text { Assessed by crude correlations, mean } \\
\text { or median differences and exact level } \\
\text { of agreement } \\
\text { Moderate agreement for fruit and low } \\
\text { agreement for vegetables }\end{array}$ & $\begin{array}{l}\text { Interval: } 10-30 \mathrm{~d}^{(138)} \\
\text { Reproducibility of FFQ is fair }\end{array}$ \\
\hline $\operatorname{MGSD}^{(79)}$ & Cross-sectional & $\begin{array}{l}\text { Adults }(n \text { 4254) } \\
\text { Non-diabetics } \\
\quad(n \text { 1833) }\end{array}$ & $\begin{array}{l}6 \text { (Greece, Italy, Algeria, } \\
\text { Bulgaria, Egypt, } \\
\text { Yugoslavia (only diabetics } \\
\text { in Yugoslavia)) }\end{array}$ & $\begin{array}{l}\text { Dietary history method } \\
\text { using questionnaire }\end{array}$ & Validated using diet records ${ }^{(79)}$ & No details $\ddagger$ \\
\hline NORBAGREEN ${ }^{(41,80)}$ & Cross-sectional & $\begin{array}{l}\text { Adults and adolescents } \\
\quad(n \text { 8397) }\end{array}$ & $\begin{array}{l}8 \text { (Norway, Denmark, } \\
\text { Sweden, Finland, Latvia, } \\
\text { Lithuania, Estonia, } \\
\text { Iceland) }\end{array}$ & FFQ† & $\begin{array}{l}\text { Validated using } 3 \mathrm{~d} \text { diet records in } \\
\text { Finland and four } 24-\mathrm{HDR} \text { in } \\
\text { Lithuania } \\
\text { Ass) } \\
\text { Assessed by crude correlations, mean } \\
\text { or median differences, and exact level } \\
\text { of agreement } \\
\text { FFQ is valid to rank individuals } \\
\text { according to F\&V intake }\end{array}$ & $\begin{array}{l}\text { Interval: } 6-8 \text { months }{ }^{(80)} \\
\text { Provides reproducible estimates } \\
\quad \text { of food group intake }\end{array}$ \\
\hline $\begin{array}{l}\text { North/South Food } \\
\text { Consumption Survey }{ }^{(45,81)}\end{array}$ & Cross-sectional & Adults ( $n$ 1379) & $\begin{array}{l}2 \text { (Northern Ireland, Republic } \\
\text { of Ireland) }\end{array}$ & $7 \mathrm{~d}$ record & No details $\ddagger$ & No details $\ddagger$ \\
\hline O'Neill et al. ${ }^{(82)}$ & Cross-sectional & Adults ( $n$ 400) & $\begin{array}{l}5 \text { (UK, Republic of Ireland, } \\
\text { Spain, France, } \\
\text { Netherlands) }\end{array}$ & FFQ† & No details $\ddagger$ & No details $\ddagger$ \\
\hline Parfitt et al. ${ }^{(83)}$ & Cross-sectional & Adults/students $(n 48)$ & 2 (England, Italy) & 5-7 d record & No details $\ddagger$ & No detailsł \\
\hline $\mathrm{PRIME}^{(84)}$ & Cohort & $\begin{array}{l}\text { Adults ( } n 8087 \text { used for } \\
\text { present study) }\end{array}$ & 2 (Northern Ireland, France) & FFQ & $\begin{array}{l}\text { Not validated against another dietary } \\
\text { assessment method. A correlation } \\
\text { analysis between the frequency of fruit } \\
\text { and/or vegetable intake and plasma } \\
\text { vitamins was performed in } 100 \text { men to } \\
\text { assess the ability of the questionnaire } \\
\text { to discriminate large } v \text {. small } \\
\text { consumers of fruits and vegetables }{ }^{(84)}\end{array}$ & No details $\ddagger$ \\
\hline
\end{tabular}


Table 2 Continued

\begin{tabular}{|c|c|c|c|c|c|c|}
\hline Study & Design & Population & Countries & Instrument(s) & Validation & Reproducibility \\
\hline PRO GREENS ${ }^{(85)}$ & Cross-sectional & Adults/parents & $\begin{array}{l}10 \text { (Austria, Belgium, } \\
\text { Denmark, Iceland, } \\
\text { Netherlands, Norway, } \\
\text { Portugal, Spain, Sweden, } \\
\text { Finland) }\end{array}$ & $\begin{array}{l}\text { A pre-coded 24-HDR }, \\
\text { FFQ } \dagger\end{array}$ & No details $\ddagger$ & No details $\ddagger$ \\
\hline Pro-Children study ${ }^{(42,86,87)}$ & Cross-sectional & $\begin{array}{l}\text { Adults/parents } \\
\text { Number NR }\end{array}$ & 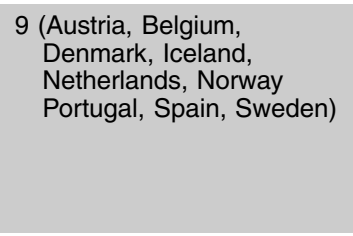 & $\begin{array}{l}\text { A pre-coded 24-HDR†, } \\
\text { FFQ } t\end{array}$ & $\begin{array}{l}\text { Validated using } 7 \mathrm{~d} \text { diet records }(1 \mathrm{~d} \\
\text { weighed record and } 6 \mathrm{~d} \text { record using } \\
\text { household measures) }(130) \\
\text { Assessed by crude correlations, mean } \\
\text { or median differences, and exact level } \\
\text { of agreement } \\
\text { FFQ valid for ranking adults according to } \\
\text { usual intake }\end{array}$ & No details $\ddagger$ \\
\hline Rylander et al. ${ }^{(88)}$ & Cross-sectional & Adults/women ( $n$ 6785) & 2 (Sweden, Switzerland) & FFQ & No detailsł & No detailsł \\
\hline $\operatorname{SENECA}^{(43,44,89,90)}$ & $\begin{array}{l}\text { Mixed design } \\
\text { (longitudinal } \\
\text { and cross- } \\
\text { sectional) }\end{array}$ & $\begin{array}{l}\text { Adults/elderly } \\
(n \approx 2600) \\
70-75 \text { years }\end{array}$ & $\begin{array}{l}12 \text { (Belgium, Denmark, } \\
\text { France, Greece, Hungary, } \\
\text { Italy, Netherlands, Norway, } \\
\text { Poland, Portugal, Spain, } \\
\text { Switzerland) }\end{array}$ & $\begin{array}{l}\text { Modified dietary history } \\
\text { method comprising a } \\
3 \mathrm{~d} \text { estimated record } \\
\text { and meal-based } \\
\text { frequency checklist }\end{array}$ & $\begin{array}{l}\text { Validated against a } 3 \mathrm{~d} \text { weighed } \\
\text { record }{ }^{(89)} \\
\text { No validation data for F\&V }\end{array}$ & No details $\ddagger$ \\
\hline $\begin{array}{l}\text { Seven Countries } \\
\text { Study }^{(4,91,92)}\end{array}$ & Cross-sectional & $\begin{array}{l}\text { Adults/men ( } n 12763 \\
\text { (enrolled)) } \\
40-59 \text { years (at } \\
\text { enrolment) }\end{array}$ & $\begin{array}{l}7 \text { (Netherlands, Finland, } \\
\text { Yugoslavia, Japan, Italy, } \\
\text { Greece, USA) }\end{array}$ & $\begin{array}{l}\text { Cross-check dietary } \\
\text { history method } \\
\text { European cohorts }(n 14) \\
\text { used } 7 \mathrm{~d} \text { records at } \\
\text { baseline }\end{array}$ & No details $\ddagger$ & $\begin{array}{l}\text { Interval: } 3 \text { and } 12 \text { months after the initial } \\
\text { surveys }{ }^{(104)} \\
\text { Small differences in reproducibility } \\
\text { estimates }\end{array}$ \\
\hline Terry et al. ${ }^{(93)}$ & Case-control & $\begin{array}{l}\text { Adults/controls } \\
\quad(n 2486) \\
20-82 \text { years }\end{array}$ & 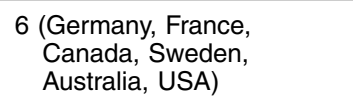 & FFQ & No details $\ddagger$ & No details $\ddagger$ \\
\hline Tessier et al. ${ }^{(94)}$ & Cross-sectional & $\begin{array}{l}\text { Adults/women } \\
\text { ( } n 123 \text { mother/ } \\
\text { daughter pairs }) \\
50-91 \text { years } \\
22-60 \text { years }\end{array}$ & 2 (Malta, Italy) & $\begin{array}{l}\text { Open-ended qualitative } \\
\text { questionnaire }\end{array}$ & No details $\ddagger$ & No details $\ddagger$ \\
\hline ToyBox ${ }^{(95-106)}$ & $\begin{array}{l}\text { Intervention } \\
\text { multifactorial } \\
\text { study }\end{array}$ & $\begin{array}{l}\text { Adults/parents } \\
\text { Number NR } \\
\text { Age range NR }\end{array}$ & $\begin{array}{l}6 \text { (Belgium, Bulgaria, } \\
\text { Germany, Greece, Poland, } \\
\text { Spain) }\end{array}$ & $\begin{array}{l}\text { Primary caregiver's FFQ } \\
(\mathrm{PCQ}) \dagger\end{array}$ & No detailsł & $\begin{array}{l}\text { Test-retest reliability of the PCQ was } \\
\text { assessed after 2-week interval|(112) } \\
\text { No data for F\&V }\end{array}$ \\
\hline Van Diepen et al..$^{(107)}$ & Cross-sectional & $\begin{array}{l}\text { Adults/students } \\
(n 185) \\
\text { Age range NR }\end{array}$ & 2 (Greece, Netherlands) & $2 \times$ consecutive $24-\mathrm{HDR}$ & No details $\ddagger$ & No details $\ddagger$ \\
\hline $\begin{array}{l}\text { WHO-MONICA EC/MONICA } \\
\text { Project optional nutrition } \\
\text { study }^{466,108,123)}\end{array}$ & Cross-sectional & $\begin{array}{l}\text { Adults }(n 7226) \\
45-64 \text { years }\end{array}$ & $\begin{array}{l}9 \text { (Northern Ireland, UK } \\
\text { (Cardiff), Denmark, } \\
\text { Finland, Belgium, } \\
\text { Germany, France, Italy, } \\
\text { Spain) }\end{array}$ & $\begin{array}{l}3 \mathrm{~d} \text { record and } 7 \mathrm{~d} \text { record } \\
\text { One centre used } 3 \times 24- \\
\text { HDR }\end{array}$ & No detailsł & No detailsł \\
\hline
\end{tabular}


Table 2 Continued

\begin{tabular}{|c|c|c|c|c|c|c|}
\hline Study & Design & Population & Countries & Instrument(s) & Validation & Reproducibility \\
\hline \multicolumn{7}{|l|}{ Adolescents } \\
\hline Gerrits et al. ${ }^{(109)}$ & Cross-sectional & $\begin{array}{l}\text { Adolescents }(n 537) \\
14-19 \text { years }\end{array}$ & $\begin{array}{l}3 \text { (Netherlands, Hungary, } \\
\text { USA) }\end{array}$ & FFQ & No detailsł & No details $\ddagger$ \\
\hline $\operatorname{HBSC}^{(31,110)}$ & Cross-sectional & $\begin{array}{l}\text { Adolescents ( } n \\
209320) \\
11-, 13-\text { and } 15 \text {-year- } \\
\text { olds }\end{array}$ & $\begin{array}{l}37 \text { (England, Norway, } \\
\text { Macedonia, Iceland, } \\
\text { Netherlands, Portugal, } \\
\text { Wales, Italy, Sweden, } \\
\text { Latvia, Switzerland, } \\
\text { Denmark, Estonia, } \\
\text { Scotland, Slovenia, } \\
\text { Ukraine, Belgium, Finland, } \\
\text { Greece, Croatia, Hungary, } \\
\text { Lithuania, Poland, } \\
\text { Germany, Greenland, } \\
\text { Russia, Armenia, Austria, } \\
\text { Belgium, Spain, France, } \\
\text { Romania, Turkey, Czech } \\
\text { Republic, Ireland, } \\
\text { Luxembourg, Slovakia) }\end{array}$ & FFQ† & $\begin{array}{l}\text { Validated using } 24 \mathrm{~h} \text { food behaviour } \\
\text { checklist and a } 7 \mathrm{~d} \text { food diary }{ }^{(132)} \\
\text { Assessed by crude correlations, energy- } \\
\text { adjusted correlations, and mean or } \\
\text { median differences in F\&V } \\
\text { consumption } \\
\text { Good agreement but overestimation of } \\
\text { intakes by FFQ } v .7 \text { d diary }\end{array}$ & $\begin{array}{l}\text { Interval: } 7-15 \mathrm{~d}^{(123)} \\
\text { Provides reproducible estimates of food } \\
\text { group intake }\end{array}$ \\
\hline HELENA $^{(32-36,50,111,112)}$ & Cross-sectional & $\begin{array}{l}\text { Adolescents }(n 3000) \\
13-17 \text { years }\end{array}$ & $\begin{array}{l}9 \text { (Greece, Germany, } \\
\text { Belgium, France, Hungary, } \\
\text { Italy, Sweden, Austria, } \\
\text { Spain) } \\
8 \text { countries included for } \\
24-H D R \text { (as above, except } \\
\text { Hungary) } \\
\text { Only Belgium tested the } \\
\text { online FFQ } \\
5 \text { (Austria, Belgium, Greece, } \\
\text { Sweden, Germany) pilot- } \\
\text { tested the online FFQ }\end{array}$ & $\begin{array}{l}\text { 24-HDR HELENA-DIAT } \\
\text { (Dietary Assessment } \\
\text { Tool)† } \\
\text { Online FFQ }\end{array}$ & $\begin{array}{l}\text { YANA-C validated using food records } \\
\text { and } 24 \mathrm{~h} \text { dietary recall interviews }{ }^{(35)} \\
\text { Assessed by crude correlations and } \\
\text { median or mean differences } \\
\text { Good agreement between intakes } \\
\text { assessed by } 24-\mathrm{HDR} \text { administered by } \\
\text { self-report and interview } \\
\text { Validated using four computerised } \\
24-\mathrm{HDR}^{(35,121)} \\
\text { Overestimation for vegetables }\end{array}$ & $\begin{array}{l}\text { Interval: } 1-2 \text { weeks } \\
\text { HELENA FFQ has adequate reliability }\end{array}$ \\
\hline Larsson et al. ${ }^{(113)}$ & Cross-sectional & $\begin{array}{l}\text { Adolescents }(n \text { 2041) } \\
\text { Age range NR }\end{array}$ & 2 (Sweden, Norway) & FFQ† & No details $\ddagger$ & No details $\ddagger$ \\
\hline Szczepanska et al..$^{(114)}$ & Cross-sectional & $\begin{array}{l}\text { Adolescents ( } n \text { 404) } \\
\text { Age range NR }\end{array}$ & 2 (Poland, Czech Republic) & FFQ† & No details $\ddagger$ & No detailsł \\
\hline TEMPEST $^{(115)}$ & Cross-sectional & $\begin{array}{l}\text { Adolescents }(n \text { 2764) } \\
12-17 \text { years }\end{array}$ & $\begin{array}{l}4 \text { (Netherlands, Poland, UK, } \\
\text { Portugal) }\end{array}$ & FFQ† & No details $\ddagger$ & No details $\ddagger$ \\
\hline I.Family Project ${ }^{(50,73,74)}$ & $\begin{array}{l}\text { Prospective } \\
\text { cohort study } \\
\text { (successor of } \\
\text { IDEFICS study) }\end{array}$ & $\begin{array}{l}\text { Adolescents ( } n>9000 \\
\text { children of IDEFICs } \\
\text { study and their } \\
\text { siblings) } \\
12-17 \text { years }\end{array}$ & $\begin{array}{l}8 \text { (Belgium, Cyprus, Estonia, } \\
\text { Germany Hungary, Italy, } \\
\text { Spain, Sweden) }\end{array}$ & $\begin{array}{l}\text { Diet questionnaire as part } \\
\text { of the parent } \\
\text { questionnaire } \\
\text { Online 24-HDR } \\
\text { (SACANA) }\end{array}$ & $\begin{array}{l}\text { Instruments are similar to validated } \\
\text { instruments used in the IDEFICS } \\
\text { project }\end{array}$ & No details $\ddagger$ \\
\hline \multicolumn{7}{|l|}{ Children } \\
\hline Antova et al. ${ }^{(116)}$ & Cross-sectional & $\begin{array}{l}\text { Children }(n \text { 20 271) } \\
7-11 \text { years }\end{array}$ & $\begin{array}{l}6 \text { (Bulgaria, Czech Republic, } \\
\text { Hungary, Poland, } \\
\text { Romania, Slovakia) }\end{array}$ & FFQ† & No details $\ddagger$ & No details $\ddagger$ \\
\hline
\end{tabular}


Table 2 Continued

\begin{tabular}{|c|c|c|c|c|c|c|}
\hline Study & Design & Population & Countries & Instrument(s) & Validation & Reproducibility \\
\hline ENERGY(27) & Cross-sectional & $\begin{array}{l}\text { Children }(n 7234) \\
10-12 \text { years }\end{array}$ & $\begin{array}{l}7 \text { (Belgium, Greece, } \\
\text { Hungary, Netherlands, } \\
\text { Norway, Slovenia, Spain) }\end{array}$ & $\begin{array}{l}\text { Questionnaire with FFQ } \\
\text { and 24-HDR } \dagger\end{array}$ & No detailsł & $\begin{array}{l}\text { The reliability and content validity of the } \\
\text { child questionnaires were tested } \\
\text { separately in all participating } \\
\text { countries } \\
\text { Reliability tested using a test-retest design } \\
\text { was used by comparing data from two } \\
\text { completions of the questionnaire } \\
\text { conducted } 1 \text { week apart } \\
\text { No reliability data for F\&V }\end{array}$ \\
\hline $\mathrm{EYHS}^{(30,117)}$ & Cross-sectional & $\begin{array}{l}\text { Children }(n \approx 4000) \\
9 \text { and } 15 \text { years }\end{array}$ & $\begin{array}{l}4 \text { (Denmark, Portugal, } \\
\text { Estonia, Norway) } \\
\text { (sourced study involves only } \\
\text { Sweden) }\end{array}$ & $\begin{array}{l}\text { 24-HDR, qualitative food } \\
\text { record }\end{array}$ & $\begin{array}{l}\text { Children's ability to recall what they } \\
\text { consumed during a } 24 \mathrm{~h} \text { period was } \\
\text { compared with observational data } \\
\text { collected during the same period }{ }^{(144)} \\
\text { Not conducted among European } \\
\text { population }\end{array}$ & No details $\ddagger$ \\
\hline IDEFICS $^{(37,38,118,119)}$ & $\begin{array}{l}\text { Prospective } \\
\text { cohort study } \\
\text { with an } \\
\text { embedded } \\
\text { intervention }\end{array}$ & $\begin{array}{l}\text { Children }(n 16224) \\
2-9 \text { years }\end{array}$ & $\begin{array}{l}8 \text { (Belgium, Cyprus, Estonia, } \\
\text { Germany Hungary, Italy, } \\
\text { Spain, Sweden) }\end{array}$ & $\begin{array}{l}\text { CEHQ-FFQ† } \\
\text { SACINA } 24-H D R \dagger^{(50)}\end{array}$ & $\begin{array}{l}\text { Validity was assessed using } \\
\text { biomarkers }{ }^{(140)} \text { and } 24-\mathrm{HDR}^{(38)} \text {. No } \\
\text { biomarker validation data for F\&V } \\
\text { Assessed against } 24-\mathrm{HDR} \text { by crude } \\
\text { correlations, de-attenuated correlation } \\
\text { coefficients, mean or median } \\
\text { differences, and exact level of } \\
\text { agreement } \\
\text { Association between FFQ and } 24-\mathrm{HDR} \\
\text { varied by food group and age. Low } \\
\text { agreement of FFQ with } 24-\mathrm{HDR} \\
\text { High relative validity between FFQ and } \\
24-\mathrm{HDR} \text {. FFQ can reliably estimate food } \\
\text { group intake among Spanish children } \\
\text { SACINA is based on the YANA-C } \\
\text { instrument validated as part of the } \\
\text { HELENA study }{ }^{(35,135)} \text {. SACINA was } \\
\text { validated using the doubly labelled } \\
\text { water technique }{ }^{(134)} \text {. No validation } \\
\text { data on F\&V }\end{array}$ & $\begin{array}{l}\text { Interval: } 0-354 \mathrm{~d} \text { (no fixed time } \\
\text { period) } \\
\text { CEHQ-FFQ provides reproducible } \\
\text { estimates of food group intake }\end{array}$ \\
\hline I.Family Project ${ }^{(50,73,74)}$ & $\begin{array}{l}\text { Prospective } \\
\text { cohort study } \\
\text { (successor of } \\
\text { IDEFICS study) }\end{array}$ & $\begin{array}{l}\text { Children }(n>9000 \\
\quad \text { children of IDEFICS } \\
\text { study and their } \\
\text { siblings) } \\
2-11 \text { years }\end{array}$ & $\begin{array}{l}8 \text { (Belgium, Cyprus, Estonia, } \\
\text { Germany Hungary, Italy, } \\
\text { Spain, Sweden) }\end{array}$ & $\begin{array}{l}\text { Diet Questionnaire (FFQ) } \\
\text { as part of the children's } \\
\text { questionnaire } \\
\text { Online 24-HDR } \\
\text { (SACANA) }\end{array}$ & $\begin{array}{l}\text { Instruments are similar to validated } \\
\text { instruments used as part of the } \\
\text { IDEFICS project }\end{array}$ & No detailsł \\
\hline ISAAC Phase II ${ }^{(40,120)}$ & Cross-sectional & $\begin{array}{l}\text { Children }(n \approx 63000 \\
\text { including } \\
\text { international } \\
\text { countries) } \\
\text { 8-12 years }\end{array}$ & $\begin{array}{l}15 \text { (Albania, France, Estonia, } \\
\text { Germany, Georgia, } \\
\text { Greece, Iceland, Italy, } \\
\text { Latvia, Netherlands, } \\
\text { Norway, Spain, Sweden, } \\
\text { Turkey, UK) }\end{array}$ & FFQ† & No details $\ddagger$ & No detailsł \\
\hline
\end{tabular}


Table 2 Continued

\begin{tabular}{|c|c|c|c|c|c|c|}
\hline Study & Design & Population & Countries & Instrument(s) & Validation & Reproducibility \\
\hline PRO GREENS ${ }^{(85)}$ & Cross-sectional & $\begin{array}{l}\text { Children ( } n 8159) \\
11 \text { years }\end{array}$ & $\begin{array}{l}10 \text { (Austria, Belgium, } \\
\text { Denmark, Iceland, } \\
\text { Netherlands, Norway, } \\
\text { Portugal, Spain, Sweden, } \\
\text { Finland) }\end{array}$ & $\begin{array}{l}\text { A pre-coded 24-HDR }+ \text {, } \\
\text { FFQ } \dagger\end{array}$ & $\begin{array}{l}\text { Validity of } 24-H D R \text { and FFQ was } \\
\text { tested in } 4 \text { countries (Denmark, } \\
\text { Iceland, Norway, Portugal) using a } \\
1 \mathrm{~d} \text { weighed food record and } 7 \mathrm{~d} \\
\text { food records } \\
\text { Assessed by crude correlations, mean } \\
\text { or median differences, and exact } \\
\text { level of agreement } \\
\text { FFQ: Moderately good ranking of F\&V } \\
\text { food groups in } 4 \text { countries } \\
24-H D R \text { : Valid estimates for fruit in } \\
3 \text { countries (exception Portugal) } \\
\text { Valid estimates for vegetables in } \\
2 \text { countries (exception Iceland and } \\
\text { Norway) }\end{array}$ & $\begin{array}{l}\text { Assessed in } 6 \text { countries (Belgium, } \\
\text { Denmark, Iceland, Norway, Portugal, } \\
\text { Spain) } \\
\text { Interval: } 7-12 \mathrm{~d}^{(42)} \\
\text { Good reproducibility for FFQ } \\
\text { Test-retest reliability carried out in } 5 \\
\text { countries (Norway, Spain, Denmark, } \\
\text { Portugal, Belgium) with a 1-week } \\
\text { interval(136) } \\
\text { No information on F\&V intake }\end{array}$ \\
\hline Pro-Children study ${ }^{(42,86,87)}$ & Cross-sectional & $\begin{array}{l}\text { Children ( } n 15404) \\
11 \text { years }\end{array}$ & 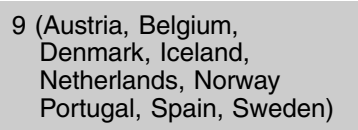 & $\begin{array}{l}\text { A pre-coded 24-HDR }+ \text {, } \\
\text { FFQ } \dagger\end{array}$ & As per PRO-GREENS ${ }^{(42,136)}$ & As per PRO-GREENS ${ }^{(42,136)}$ \\
\hline ToyBox ${ }^{(95-106)}$ & $\begin{array}{l}\text { Intervention } \\
\text { multifactorial } \\
\text { study }\end{array}$ & $\begin{array}{l}\text { Children ( } n \text { 5472) } \\
3.5-5.5 \text { years }\end{array}$ & $\begin{array}{l}6 \text { (Belgium, Bulgaria, } \\
\text { Germany, Greece, Poland, } \\
\text { Spain) }\end{array}$ & Children's FFQ† & $\begin{array}{l}\text { Validated using estimated } 3 \mathrm{~d} \text { diet } \\
\text { records }(137) \\
\text { Assessed by crude correlations, de- } \\
\text { attenuated correlation coefficients, } \\
\text { mean or median differences, and } \\
\text { exact level of agreement } \\
\text { Moderate relative validity between FFQ } \\
\text { and diet records }\end{array}$ & $\begin{array}{l}\text { Interval: at least } 5 \text { weeks }{ }^{(137)} \\
\text { FFQ provides reproducible estimates of } \\
\text { food group intake }\end{array}$ \\
\hline
\end{tabular}

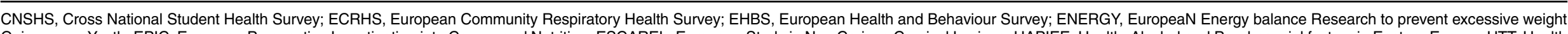

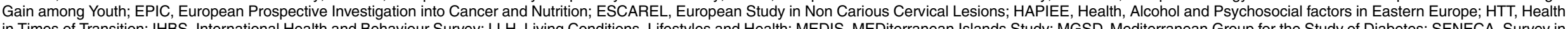

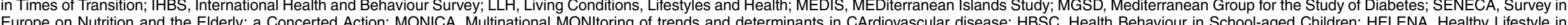

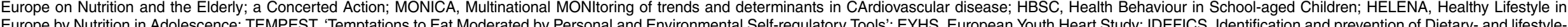

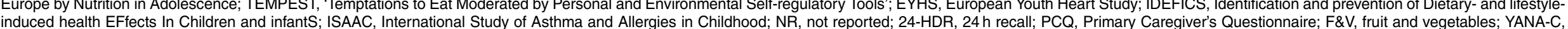
Young Adolescents' Nutrition Assessment on Computer; CEHQ, Children's Eating Habits Questionnaire.

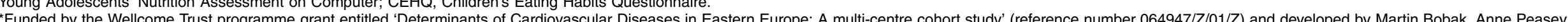
Hynek Pikhart (UCL), Ruzena Kubinova, Lubomíra Milla Novosibirsk, Sofia Malyutina, Oksana Bragina (Prague), Andrzej Pajak, Aleksandra Gilis-Januszewska (Krakow).

tOriginal instrument obtained for review.

IValidation or reproducibility of the instrument was not reported in the article and no reference to validation or reproducibility studies were provided. 
methods, in the interest of comprehensiveness, details on all the identified methods are provided.

Instruments which met the two selection criteria for which validation data on $\mathrm{F} \& \mathrm{~V}$ intake were available are summarized in Table 3. Of those for use among adults, F\&V intakes assessed by EPIC-SOFT were described by authors as having weak to moderate correlation with biomarkers $^{(63)}$. The Food4Me FFQ was reported to demonstrate moderate agreement with a $4 \mathrm{~d}$ weighed food record ${ }^{(53)}$ and good agreement with the EPICNorfolk $\mathrm{FFQ}^{(52)}$. While the ToyBox Primary Caregiver's Questionnaire was tested for reliability there were no data available for F\&V. Similarly, the ENERGY parent questionnaire was tested for reliability but data were unpublished. The Seven Countries Study dietary history instrument was not validated but reproducible ${ }^{(131)}$. HELENA-DIAT, administered by self-report, was reported to have good agreement with intakes when administered by interview ${ }^{(35)}$. The HELENA-FFQ was found to have adequate reliability ${ }^{(36)}$. The HBSC FFQ was found to be reproducible and reported to have good agreement with a $7 \mathrm{~d}$ food diary $^{(132)}$.

The IDEFICS FFQ was compared with two 24-HDR but had low agreement with 24-HDR according to the authors, and agreement varied by food group and age of child in a population across eight survey sites ${ }^{(38)}$. However, the instrument had good agreement with $24-H D R$ in a sample of Spanish children ${ }^{(135)}$ and has been demonstrated to be reproducible ${ }^{(145)}$. The Pro-Children instrument, when compared with $7 \mathrm{~d}^{(130)}$ and $1 \mathrm{~d}^{(42)}$ diet records, was reported to have moderate to good validity for ranking individuals according to usual intake and was reproducible $^{(42)}$. The ToyBox study instrument was shown to be reproducible and was reported to have moderate relative validity when compared with $3 \mathrm{~d}$ diet records ${ }^{(137)}$.

\section{FFQ}

Range of items and definitions

Characteristics of the identified FFQ are summarised in Table 4. FFQ were used to assess dietary intake, identify determinants of dietary intake, or test diet-disease associations and identify disease risk factors. The number of food items listed on these FFQ ranged between sixty-six and 322 , with the number of items relating to fruit and vegetables ranging from one item ${ }^{(27,60)}$ to ninety-five items ${ }^{(82)}$. Several FFQ used non-itemised terms such as 'fruit', 'vegetables', 'fresh fruit', 'raw vegetables' and 'cooked vegetables '(37,42,48,56,58,64,66,67,69,75,84,100,109,110,114-116,120), while others listed individual fruits and vegetables ${ }^{(30,39,41,52,53,82,150)}$. FFQ could be classed as having low $(<5$ items relating to fruit or vegetables) or high ( $>5$ items relating to fruit or vegetables) comprehensiveness based on the cut-off used by Cook et $a l .{ }^{(151)}$. Thirteen FFQ were classed as having low comprehensiveness for $\mathrm{F} \& \mathrm{~V}$, including the ENERGY and HBSC questionnaires $^{(27,31,48,56,57,64,66,71,75,114-116,120)}$.
Some FFQ further subdivided F\&V into 'raw/fresh', 'cooked' or 'tinned', each with separate items listed underneath $^{(150)}$. The NORBAGREEN FFQ ${ }^{(41)}$ and the FFQ used by Larsson et al. ${ }^{(113)}$ assessed the consumption of individual fruits and vegetables, but also included a crosscheck question on the total consumption of vegetables and fruits. The NORBAGREEN FFQ assessed consumption within different contexts and using different cooking styles; for example, asking participants to report the frequency of consumption of 'cooked, canned or steamed vegetables' and of 'dried fruit or berries'.

Where individual F\&V items were listed, FFQ also varied in terms of whether pulses ${ }^{(38,82)}$ or potatoes ${ }^{(58,109)}$ were included under 'vegetables'. Some FFQ listed potatoes as 'cooked vegetables',(38,67), 'white-yellowish vegetables' ${ }^{(82)}$ or specified 'vegetables (potatoes excluded), ${ }^{\text {(71,113) }}$. Many FFQ listed separate potato items or 'potatoes' and 'legumes/ pulses' as separate group headings with their own items listed below $(30,36,38,39,48,52,53,66,100,113,150)$. With some exceptions $^{(52,53,86,104)}$, if an FFQ listed fruit or vegetable juice it did not always specify $100 \%$ fruit or vegetable juice ${ }^{(27,86,100)}$. Therefore, participants could interpret this as including fruit squash and dilutions.

\section{Mode and structure}

All FFQ were paper-based and self-administered with some exceptions in which the FFQ was web-based ${ }^{(51)}$, administered via face-to-face interview ${ }^{(93,147)}$ or by computerassisted telephone interview ${ }^{(41)}$. Most of the identified FFQ used pre-coded frequency categories. The majority provided a single frequency scale with typically five or six categories extending from 'never', 'less than once a month' or 'less than once a week' to 'every day', 'more than once a day', 'more than $X$ times per day' or 'several times a day'(31,40,48,104,113,114,122), although the ENERGY FFQ asked participants to select from seven frequency options per week or six frequency options per day. The ESCAREL (European Study in Non Carious Cervical Lesions) FFQ provided a two-step frequency scale: participants first specified whether they consumed fruit juice 'often' and then provided a frequency from 'more than three times per week' to 'less than once per week'.

\section{Time period}

Most FFQ specified the time period to which consumption frequency referred, generally the previous 12 months. However, other time periods were used, including the previous 3-4 months ${ }^{(82)}, 3$ months $^{(70)}, 1$ month $^{(48,52-54)}$ and 1 week $^{(27,66,71,110,139)}$, or consumption on an average day $^{(115)}$. The remaining FFQ did not provide a specific time period and participants were directed to report usual or habitual intake. Some FFQ assessed consumption of certain F\&V by season ${ }^{(65,116)}$.

\section{Portion size estimation}

The majority of FFQ were semi-quantitative and assessed both frequency and amount; in most cases, assessing portion 
Table 3 Summary of the selected instruments which were validated $(n)$ for assessment of fruit and vegetables

\begin{tabular}{|c|c|c|c|c|c|}
\hline Study/instrument & Design & Age group & Countries & Mode & Portion estimation \\
\hline $\begin{array}{l}\text { Adults } \\
\text { EPIC }{ }^{(18,28,29,61-63)} \\
\text { EPIC-SOFT 24-HDR }\end{array}$ & Cohort & $30-70$ years & $\begin{array}{l}10 \text { (Italy, Spain, Netherlands, Germany, Sweden } \\
\text { (Malmo)/Sweden(Umea), Denmark, France, } \\
\text { Greece, Norway, England) }\end{array}$ & $\begin{array}{l}\text { Face-to-face interview } \\
\text { Computerised }\end{array}$ & $\mathrm{x}$ \\
\hline $\begin{array}{l}\text { Food4Me } e^{(51-53)} \\
\text { Web-based FFQ }\end{array}$ & Randomised controlled trial & $17-79$ years & $\begin{array}{l}7 \text { (Ireland, Netherlands, Spain, Greece, UK, Poland, } \\
\text { Germany) }\end{array}$ & Self-admin. & $x$ \\
\hline $\begin{array}{l}\text { Adolescents } \\
\text { HBSC(31,110) } \\
\text { FFQ }\end{array}$ & Cross-sectional & $\begin{array}{l}\text { 11-, 13- and } \\
15 \text {-year-olds }\end{array}$ & $\begin{array}{l}37 \text { (England, Norway, Macedonia, Iceland, } \\
\text { Netherlands, Portugal, Wales, Italy, Sweden, } \\
\text { Latvia, Switzerland, Denmark, Estonia, Scotland, } \\
\text { Slovenia, Ukraine, Belgium, Finland, Greece, } \\
\text { Croatia, Hungary, Lithuania, Poland, Germany, } \\
\text { Greenland, Russia, Armenia, Austria, Belgium, } \\
\text { Spain, France, Romania, Turkey, Czech Republic, } \\
\text { Ireland, Luxembourg, Slovakia) }\end{array}$ & Self-admin. & \\
\hline $\begin{array}{l}\text { HELENA }(32-36,50,111,112) \\
\text { 24-HDR } \\
\text { HELENA-DIAT }\end{array}$ & Cross-sectional & 13-17 years & $\begin{array}{l}8 \text { (Greece, Germany, Belgium, France, Italy, } \\
\text { Sweden, Austria, Spain) }\end{array}$ & $\begin{array}{l}\text { Self-admin. } \\
\text { Computerised }\end{array}$ & $\mathrm{x}$ \\
\hline $\begin{array}{l}\text { HELENA }{ }^{(32-36,50,111,112)} \\
\text { Online FFQ }\end{array}$ & & 13-17 years & 5 (Austria, Belgium, Greece, Sweden, Germany) & Self-admin. & $x$ \\
\hline $\begin{array}{l}\text { Children } \\
\text { IDEFICS }^{(37,118,119)} \\
\text { CEHQ-FFQ* }^{*}\end{array}$ & $\begin{array}{l}\text { Prospective cohort study } \\
\text { with an embedded } \\
\text { intervention }\end{array}$ & $2-9$ years & $\begin{array}{l}8 \text { (Belgium, Cyprus, Estonia, Germany Hungary, } \\
\text { Italy, Spain, Sweden) }\end{array}$ & Self-admin. (parents) & \\
\hline $\begin{array}{l}\text { Pro-Children study }{ }^{(42,86,87)} \\
\text { A pre-coded } 24-\mathrm{HDR}^{*}, \mathrm{FFQ}^{*}\end{array}$ & Cross-sectional & 11 years & $\begin{array}{l}9 \text { (Austria, Belgium, Denmark, Iceland, } \\
\text { Netherlands, Norway Portugal, Spain, Sweden) }\end{array}$ & Self-admin. & $x$ \\
\hline $\begin{array}{l}\text { ToyBox }{ }^{(95-106)} \\
\text { Children's FFQ* }\end{array}$ & $\begin{array}{l}\text { Intervention multifactorial } \\
\text { study }\end{array}$ & $3.5-5.5$ years & $\begin{array}{l}6 \text { (Belgium, Bulgaria, Germany, Greece, Poland, } \\
\text { Spain) }\end{array}$ & Self-admin. & $\mathrm{x}$ \\
\hline
\end{tabular}

EPIC, European Prospective Investigation into Cancer and Nutrition; 24-HDR, 24 h recall; HBSC, Health Behaviour in School-aged Children; HELENA, Healthy Lifestyle in Europe by Nutrition in Adolescence; IDEFICS, Identification and prevention of Dietary- and lifestyle-induced health EFfects In Children and infants; CEHQ, Children's Eating Habits Questionnaire; self-admin., self-administered.

*Original instrument obtained for review. 
Table 4 Summary of FFQ: instrument purpose and characteristics

\begin{tabular}{|c|c|c|c|c|c|c|c|c|}
\hline Study & Type/no. of items & Purpose & Population & F\&V items \& classification & Reference period & Mode & Categories & Portion estimation \\
\hline \multirow{2}{*}{$\begin{array}{l}\text { Adults } \\
\text { Baldini et al. }{ }^{(54) *}\end{array}$} & & & & & & & & \\
\hline & $\begin{array}{l}\text { Semi-quantitative } \\
\text { Sixty-one-item FFQ }\end{array}$ & $\begin{array}{l}\text { Assess dietary habits } \\
\text { Assess influence of } \\
\text { lifestyle on energy } \\
\text { balance and BMI }\end{array}$ & $\begin{array}{l}\text { Adults/students } \\
\text { Age range NR }\end{array}$ & $\begin{array}{l}\text { Exact classification unknown† } \\
\text { Used Willett FFQ }\end{array}$ & Previous month & Self-admin. & $\begin{array}{l}\text { Detailed record of food } \\
\text { consumption, starting from } \\
\text { breakfast and ending at } \\
\text { bedtime } \\
9 \text { categories, ranging from } \\
\text { 'never' to ' } 6 \text { or more times } \\
\text { per day' }\end{array}$ & $\begin{array}{l}\text { Yes } \\
\text { Assessed separately } \\
\text { Pictures of standard meal/food } \\
\text { sizes } \\
\text { Used natural units if possible } \\
\text { A full description of usual } \\
\text { serving size was provided } \\
\text { for each item }\end{array}$ \\
\hline Behanova et al. ${ }^{(56) *}$ & $\begin{array}{l}\text { Semi-quantitative } \\
\text { General } \\
\quad \text { questionnaire }\end{array}$ & $\begin{array}{r}\text { Determine prevalence of } \\
\text { health-risk behaviours }\end{array}$ & $\begin{array}{l}\text { Adults } \\
19-64 \text { years }\end{array}$ & $\begin{array}{l}\text { Non-itemised } \\
\text { Two items: } \\
\text { 'Portions of vegetables' } \\
\text { 'Portions of fruits' (including } \\
\text { dried fruit, fruit juice) }\end{array}$ & NR & Self-admin. & $\begin{array}{l}\text { Open-ended } \\
\text { Subject to report a number of } \\
\text { portions }\end{array}$ & $\begin{array}{l}\text { Yes } \\
\text { Assessed in-line } \\
\text { Examples given for } 1 \text { portion, } \\
\text { e.g. handful of dried fruit, } \\
\text { heaped tablespoon of } \\
\text { carrots }\end{array}$ \\
\hline $\mathrm{CNSHS}^{(57,58)}$ & $\begin{array}{l}\text { Non-quantitative } \\
\text { General } \\
\text { questionnaire }\end{array}$ & $\begin{array}{l}\text { Test association between } \\
\text { food patterns and living } \\
\text { arrangements }(57) \\
\text { Test association between } \\
\text { diet and stress/ } \\
\text { depressive } \\
\text { symptoms }^{(58)}\end{array}$ & $\begin{array}{l}\text { Adults/students } \\
\text { Age range NR }\end{array}$ & $\begin{array}{l}\text { Four items: } \\
\text { 'Fresh fruits' } \\
\text { 'Raw vegetables' } \\
\text { 'Cooked vegetables' } \\
\text { 'Salads' }\end{array}$ & NR & Self-admin. & $\begin{array}{l}5 \text { categories, ranging from } \\
\text { 'several times a day' to ' } 1-4 \\
\text { times a month' and 'never' }\end{array}$ & No \\
\hline ENERGY $Y^{(27) *}$ & $\begin{array}{l}\text { Semi-quantitative } \\
\text { General } \\
\quad \text { questionnaire }\end{array}$ & $\begin{array}{l}\text { Determine prevalence of } \\
\text { EBRB } \\
\text { Identify personal, family } \\
\text { and school } \\
\text { environmental correlates } \\
\text { of EBRB }\end{array}$ & $\begin{array}{l}\text { Adults/caregivers } \\
\text { Age range NR }\end{array}$ & $\begin{array}{l}\text { One item: } \\
\text { Fruit juices. 'When we say } \\
\text { fruit juices we mean the } \\
\text { packed fruit juice and } \\
\text { freshly blended juice at } \\
\text { home ( } 100 \% \text { fruit juice)' } \\
\text { Examples provided }\end{array}$ & $\begin{array}{l}\text { Previous week } \\
\text { Usual consumption } \\
\text { on a day on } \\
\text { which fruit juices } \\
\text { are drunk }\end{array}$ & Self-admin. & $\begin{array}{l}7 \text { categories per week } \\
6 \text { categories per day }\end{array}$ & $\begin{array}{l}\text { Yes } \\
\text { Assessed in-line } \\
\text { Subject can select number of } \\
\text { glasses/small cartons } \\
(250 \mathrm{ml}) \text { and regular cartons } \\
(330 \mathrm{ml}) \text { drank on a day of } \\
\text { consumption }\end{array}$ \\
\hline $\mathrm{EHBS}^{(60)}$ & Refer to IHBS & $\begin{array}{l}\text { Test association between } \\
\text { health locus of control } \\
\text { and health behaviour }\end{array}$ & Refer to IHBS & $\begin{array}{l}\text { One item: } \\
\text { 'Fruit consumption' }\end{array}$ & Refer to IHBS & Refer to IHBS & Refer to IHBS & Refer to IHBS \\
\hline ESCAREL $^{(64) *}$ & $\begin{array}{l}\text { Non-quantitative } \\
\text { Five-item FFQ } \\
\text { within a general } \\
\text { questionnaire }\end{array}$ & $\begin{array}{l}\text { Assess the prevalence of } \\
\text { tooth wear on buccal/ } \\
\text { facial and lingual/palatal } \\
\text { tooth surfaces } \\
\text { Identify related risk factors } \\
\text { (i.e. fresh fruit and juice } \\
\text { intake) }\end{array}$ & $\begin{array}{l}\text { Adults } \\
18-35 \text { years }\end{array}$ & $\begin{array}{l}\text { Two items: } \\
\text { 'Fresh fruit, e.g. lemon, } \\
\text { orange, apple, pear, } \\
\text { grapes, mango, etc.' } \\
\text { 'Fruit and vegetable juice, e.g. } \\
\text { orange, apple, grape, } \\
\text { pineapple, carrot, } \\
\text { multivitamin, etc.' }\end{array}$ & NR & Self-admin. & $\begin{array}{l}4 \text { categories: 'often', 'rarely', } \\
\text { 'never' and 'don't know', } \\
\text { For items ranked as 'often' a } \\
\text { choice of } 5 \text { categories, } \\
\text { ranging from 'more than } 3 \\
\text { times per week' to 'less than } \\
\text { once per week' }\end{array}$ & No \\
\hline Esteve et al. ${ }^{(65)}$ & $\begin{array}{l}\text { Semi-quantitative } \\
\text { Dietary } \\
\quad \text { questionnaire }\end{array}$ & $\begin{array}{l}\text { Test association between } \\
\text { diet and cancers of the } \\
\text { larynx and hypopharynx }\end{array}$ & $\begin{array}{l}\text { Adults } \\
\text { Age range NR }\end{array}$ & $\begin{array}{l}\text { Exact classification unknownt } \\
\text { Seasonality of } F \& V \text { assessed }\end{array}$ & 12 months & $\begin{array}{l}\text { Face-to-face } \\
\text { interview }\end{array}$ & $\begin{array}{l}\text { Structured by meals, i.e. } \\
\text { breakfast, lunch, dinner, as } \\
\text { well as early morning, mid- } \\
\text { morning, mid-afternoon and } \\
\text { late evening snacks }\end{array}$ & $\begin{array}{l}\text { Yes } \\
\text { Assessed separately } \\
\text { Usual portion size estimated } \\
\quad \text { during interview. Method NR }\end{array}$ \\
\hline $\begin{array}{l}\text { Finbalt Health } \\
\text { Monitor }\end{array}$ & $\begin{array}{l}\text { Non-quantitative } \\
\text { Seventeen-item } \\
\text { FFQ within } \\
\text { general } \\
\text { questionnaire }\end{array}$ & $\begin{array}{l}\text { Assess gender differences } \\
\text { in F\&V consumption }\end{array}$ & $\begin{array}{l}\text { Adults } \\
20-64 \text { years }\end{array}$ & $\begin{array}{l}\text { Four items: } \\
\text { 'Fresh vegetables' } \\
\text { 'Other vegetables', } \\
\text { 'Fresh fruit/berries' } \\
\text { 'Other fruit/berries' } \\
\text { Potatoes assessed separately }\end{array}$ & Previous week & Self-admin. & $\begin{array}{l}4 \text { categories: 'never', } \\
\text { '1-2 days', ' } 3-5 \text { days' and } \\
\text { '6-7 days' }\end{array}$ & No \\
\hline
\end{tabular}


Table 4 Continued

\begin{tabular}{|c|c|c|c|c|c|c|c|c|}
\hline Study & Type/no. of items & Purpose & Population & $\mathrm{F} \& \mathrm{~V}$ items \& classification & Reference period & Mode & Categories & Portion estimation \\
\hline Food4Me ${ }^{(51-53)} \ddagger$ & $\begin{array}{l}\text { Semi-quantitative } \\
\text { Web-based 157- } \\
\text { item FFQ }\end{array}$ & $\begin{array}{l}\text { Determine impact of } \\
\text { personalised dietary } \\
\text { advice on eating } \\
\text { patterns and health } \\
\text { outcomes }\end{array}$ & $\begin{array}{l}\text { Adults } \\
18-79 \text { years }\end{array}$ & & Previous month & Self-admin. & $\begin{array}{l}9 \text { categories, ranging from } \\
\text { 'never or less than once a } \\
\text { month' to ' } 5-6 \text { times per day' } \\
\text { and ' }>6 \text { times per day' }\end{array}$ & $\begin{array}{l}\text { Yes } \\
3 \text { photographs representing } \\
\text { small, medium and large } \\
\text { portions } \\
\text { Participants could select one of } \\
\text { the following options: very } \\
\text { small, small, small/medium, } \\
\text { medium, medium/large, large } \\
\text { or very large, which were } \\
\text { linked electronically to portion } \\
\text { sizes (in grams) }\end{array}$ \\
\hline Galanti et al. ${ }^{(69)}$ & $\begin{array}{l}\text { Semi-quantitative } \\
\text { Sixty-item FFQ } \\
\text { (Norway) } \\
\text { Fifty-six-item FFQ } \\
\text { (Sweden) }\end{array}$ & $\begin{array}{l}\text { Test association between } \\
\text { diet and papillary and } \\
\text { follicular thyroid } \\
\text { carcinoma }\end{array}$ & $\begin{array}{l}\text { Adults } \\
18-60+\text { years }\end{array}$ & $\begin{array}{l}\text { Exact classification unknownt } \\
\text { Six items: } \\
\text { 'All vegetables' } \\
\text { 'Vegetables, excluding } \\
\text { cruciferous' } \\
\text { 'Cruciferous vegetables' } \\
\text { 'All fruit (piece)' } \\
\text { 'Apple' } \\
\text { 'Citrus fruit' }\end{array}$ & $\mathrm{NR}$ & Self-admin. & $\begin{array}{l}\text { For foods which traditionally } \\
\text { are consumed more often } \\
\text { and for all beverages, } \\
\text { average number of servings } \\
\text { was requested, per day, } \\
\text { week or month } \\
\text { Less frequently consumed } \\
\text { foods: } 6 \text { pre-coded } \\
\text { frequencies, ranging from } \\
\text { 'never' to 'once a day or } \\
\text { more often' }\end{array}$ & $\begin{array}{l}\text { Yes } \\
\text { Assessed in-line } \\
\text { Asked to specify number of } \\
\text { servings }\end{array}$ \\
\hline HAPIEE $^{(70) *}$ & $\begin{array}{l}\text { Semi-quantitative } \\
\text { Czech =136-item } \\
\text { FFQ } \\
\text { Russian }=147 \text {-item } \\
\text { FFQ } \\
\text { Polish =148-item } \\
\text { FFQ }\end{array}$ & $\begin{array}{l}\text { Test association between } \\
\text { socio-economic } \\
\text { indicators and diet }{ }^{(147)}\end{array}$ & $\begin{array}{l}\text { Adults } \\
45-69 \text { years }\end{array}$ & $\begin{array}{l}\text { As per generic FFQ (note: } \\
\text { number of items differs } \\
\text { slightly for each local } \\
\text { adaption) } \\
\text { Fifty-three items: } \\
\text { Twenty-one items under } \\
\text { 'Fresh fruit' } \\
\text { 'Tinned or bottled fruit' } \\
\text { Thirty-one items under } \\
\text { 'Vegetables' (Pulses } \\
\text { included) } 1 \text { fruit juice } \\
\text { Potatoes assessed separately }\end{array}$ & Previous 3 months & $\begin{array}{l}\text { Interview } \\
\text { (Russia \& } \\
\text { Poland) } \\
\text { Self-admin. } \\
\text { (Czech } \\
\text { Republic) }\end{array}$ & $\begin{array}{l}9 \text { categories, ranging from } \\
\text { 'never' to 'six or more times } \\
\text { per day' } \\
\text { Open-ended section where } \\
\text { subjects could add any } \\
\text { further foods not listed }\end{array}$ & $\begin{array}{l}\text { Yes } \\
\text { Assessed in-line } \\
\text { A country-specific portion size } \\
\text { for each food was specified } \\
\text { Participants were asked how } \\
\text { often, on average, they had } \\
\text { consumed a 'medium } \\
\text { serving' of the items - } \\
\text { defined as about } 100 \mathrm{~g} \text { or } \\
50 \mathrm{~g} \text { depending on the food } \\
\text { in question }\end{array}$ \\
\hline $\mathrm{HTT}^{(71) *}$ & $\begin{array}{l}\text { Non-quantitative } \\
\text { Ten-item FFQ } \\
\text { within a general } \\
\text { questionnaire }\end{array}$ & $\begin{array}{l}\text { Identify factors associated } \\
\text { with low consumption of } \\
\text { F\&V }\end{array}$ & $\begin{array}{l}\text { Adults } \\
\text { Age range NR }\end{array}$ & $\begin{array}{l}\text { Two items: } \\
\text { 'Fresh fruit' } \\
\text { 'Fresh vegetables (except for } \\
\text { potatoes)' }\end{array}$ & Previous week & $\begin{array}{c}\text { Face-to-face } \\
\text { interview }\end{array}$ & $\begin{array}{l}4 \text { categories, ranging from } \\
\text { 'daily/almost daily' to 'less } \\
\text { than once a week' }\end{array}$ & No \\
\hline Hupkens et al. ${ }^{(72)}$ & $\begin{array}{l}\text { Semi-quantitative } \\
\text { 150-item FFQ used } \\
\text { for NCS }\end{array}$ & $\begin{array}{l}\text { Test association between } \\
\text { social class factors and } \\
\text { fat and fibre } \\
\text { consumption }\end{array}$ & $\begin{array}{l}\text { Adults } \\
55-69 \text { years }\end{array}$ & $\begin{array}{l}\text { Twenty-eight items: } \\
\text { Thirteen boiled veg items } \\
\text { Five raw veg items } \\
\text { Seven fruit items } \\
\text { Three juice items } \\
\text { Potatoes assessed separately } \\
\text { Vegetable seasonality } \\
\text { assessed }\end{array}$ & 12 months & Self-admin. & $\begin{array}{l}6 \text { categories (veg), ranging } \\
\text { from 'never' to ' } 3 \text { or } 7 \text { times } \\
\text { per week' } \\
6 \text { categories (fruit), ranging } \\
\text { from 'never' to ' } 6 \text { or } 7 \text { times } \\
\text { per week' } \\
\text { Open-ended section for foods } \\
\text { not on the FFQ }\end{array}$ & NR \\
\hline I.Family Project ${ }^{(50)}$ & $\begin{array}{l}\text { Non-quantitative } \\
\text { Sixty-item FFQ }\end{array}$ & $\begin{array}{l}\text { Assess determinants of } \\
\text { eating behaviour }\end{array}$ & $\begin{array}{l}\text { Adults/parents } \\
\text { No age range } \\
\text { determined }\end{array}$ & $\begin{array}{l}\text { Nine items: } \\
\text { Four veg items (including } \\
\text { legumes and potatoes) } \\
\text { Two fruit items (fresh with or } \\
\text { without sugar) } \\
\text { One fruit juice item } \\
\text { Nuts and dried fruits } \\
\text { separately (two items) } \\
\text { under 'snacks' }\end{array}$ & $\begin{array}{l}\text { Typical week over } \\
\text { the previous } \\
\text { month }\end{array}$ & Self-admin. & $\begin{array}{l}7 \text { categories, ranging from } \\
\text { 'never/less than once a } \\
\text { week' to '4 or more times } \\
\text { per day' }\end{array}$ & No \\
\hline
\end{tabular}


Table 4 Continued

\begin{tabular}{|c|c|c|c|c|c|c|c|c|}
\hline Study & Type/no. of items & Purpose & Population & F\&V items \& classification & Reference period & Mode & Categories & Portion estimation \\
\hline $\operatorname{IHBS}^{(75) \star}$ & $\begin{array}{l}\text { Non-quantitative } \\
\text { Two-item FFQ } \\
\text { within a general } \\
\text { questionnaire }\end{array}$ & $\begin{array}{l}\text { Test association between } \\
\text { life satisfaction and } \\
\text { health behaviours }\end{array}$ & $\begin{array}{l}\text { Adults } \\
17-30 \text { years }\end{array}$ & $\begin{array}{l}\text { One item: } \\
\text { 'Fruit' }\end{array}$ & NR & Self-admin. & $\begin{array}{l}5 \text { categories, ranging from } \\
\text { 'never' to 'at least once } \\
\text { every day' }\end{array}$ & No \\
\hline IMMIDIET $^{(39,76)}$ & $\begin{array}{l}\text { Semi-quantitative } \\
322 \text {-item } \\
\text { EPIC-Italy FFQ (as } \\
\text { above) } \\
\text { EPIC-UK FFQ (as } \\
\text { above) }\end{array}$ & $\begin{array}{l}\text { Identify determinants (diet, } \\
\text { genetic) of risk of } \\
\text { myocardial infarction }{ }^{(39)} \\
\text { Determine role of dietary } \\
\text { patterns in plasma and } \\
\text { red blood cell fatty acids } \\
\text { variation }^{(76)}\end{array}$ & $\begin{array}{l}\text { Adults } \\
26-65 \text { years }\end{array}$ & $\begin{array}{l}\text { Sixty-three items: } \\
\text { Twenty-one cooked veg items } \\
\text { Ten raw veg items } \\
\text { Thirty-two fruit items } \\
\text { (including fresh, tinned, } \\
\text { dried) } \\
\text { Potatoes and legumes } \\
\text { assessed separately }\end{array}$ & 12 months & $\begin{array}{l}\text { Face-to-face } \\
\text { interview } \\
\text { Self-admin. in } \\
\text { validity } \\
\text { study }^{40)}\end{array}$ & $\begin{array}{l}9 \text { categories, ranging from } \\
\text { 'never/rarely', ' } 1-3 \text { days/ } \\
\text { month' to ' } 1,2,3,4,5,6, \\
7 \text { days per week' }\end{array}$ & $\begin{array}{l}\text { Yes } \\
\text { Assessed separately } \\
\text { Recorded as absolute weights } \\
\text { or as household } \\
\text { measurements } \\
\text { Photo book to estimate small, } \\
\text { average and large portions } \\
\text { for spreads, bread spreads, } \\
\text { and milk in coffee and tea }\end{array}$ \\
\hline $\operatorname{LLH}^{(71) \star}$ & $\begin{array}{l}\text { Non-quantitative } \\
\text { Nine-item FFQ } \\
\text { within a general } \\
\text { questionnaire }\end{array}$ & $\begin{array}{l}\text { Identify factors associated } \\
\text { with low consumption of } \\
\text { F\&V }\end{array}$ & $\begin{array}{l}\text { Adults } \\
\text { Age range NR }\end{array}$ & $\begin{array}{l}\text { Two items: } \\
\text { 'Fruit' } \\
\text { 'Vegetables (except for } \\
\text { potatoes' }\end{array}$ & Previous week & $\begin{array}{l}\text { Face-to-face } \\
\text { interview }\end{array}$ & $\begin{array}{l}4 \text { categories, ranging from } \\
\text { 'extremely seldom' to 'daily' }\end{array}$ & No \\
\hline NORBAGREEN $^{(41,80)_{\star}}$ & $\begin{array}{l}\text { Non-quantitative } \\
\text { Fifty-six-item FFQ }\end{array}$ & $\begin{array}{l}\text { Assess the frequency of } \\
\text { consumption of } \\
\text { vegetables, potatoes, } \\
\text { fruit, bread and fish }\end{array}$ & $\begin{array}{l}\text { Adults and } \\
\text { adolescents } \\
15-74 \text { years }\end{array}$ & $\begin{array}{l}\text { Thirty-nine items: } \\
\text { Questions on global } \\
\text { 'Vegetables and roots' and } \\
\text { 'Fruits and berries' } \\
\text { consumption (including } \\
\text { pulses) } \\
\text { Nineteen veg items } \\
\text { Fourteen fruit items } \\
\text { Four potato items } \\
\text { Potatoes assessed separately }\end{array}$ & 12 months & $\begin{array}{l}\text { Using CATI in } \\
\text { the Nordic } \\
\text { countries } \\
\text { and PAPI in } \\
\text { the Baltic } \\
\text { countries }\end{array}$ & $\begin{array}{l}\text { Times per month, ranged from } \\
\text { '<1 or not at all' to ' } 3 \text { ' } \\
\text { Times per week, ranged from } \\
\text { '1' to ' } 6 \text { ' } \\
\text { Times per day, ranged from ' } 1 \text { ' } \\
\text { to ' } 4 \text { or more' }\end{array}$ & No \\
\hline $\operatorname{MGSD}^{(79) *}$ & $\begin{array}{l}\text { Semi-quantitative } \\
\text { Dietary history } \\
\text { questionnaire } \\
\text { with seventy- } \\
\text { eight items }\end{array}$ & $\begin{array}{l}\text { Compare the nutritional } \\
\text { habits among six } \\
\text { Mediterranean countries } \\
\text { and with official } \\
\text { recommendations }\end{array}$ & $\begin{array}{l}\text { Adults } \\
35-60 \text { years }\end{array}$ & $\begin{array}{l}\text { Eleven items: } \\
\text { Three 'Cooked veg' non- } \\
\text { itemised questions, each } \\
\text { with different veg group } \\
\text { One 'Raw veg' item } \\
\text { Two itemised veg (onions, } \\
\text { garlic) } \\
\text { Two 'Cooked legumes' items } \\
\text { One 'Fruit' item } \\
\text { One 'Juice' item } \\
\text { One 'Dried fruit' item } \\
\text { Potatoes assessed separately }\end{array}$ & NR & $\begin{array}{l}\text { Face-to-face } \\
\text { interview }\end{array}$ & $\begin{array}{l}\text { Enter number per day or per } \\
\text { week for pre-coded items } \\
\text { Open-ended section structured } \\
\text { by seven meals, whereby } \\
\text { subject enters the time, } \\
\text { description, quantity, and } \\
\text { whether food eaten at home } \\
\text { or in a restaurant }\end{array}$ & $\begin{array}{l}\text { Yes } \\
\text { Assessed in-line } \\
15 \mathrm{~g} \text { or about } 1 \text { tablespoon } \\
100 \mathrm{~g} \text { or } 1 \mathrm{cup} \text { (raw veg) } \\
200 \mathrm{~g} \text { or } 1 \text { cup (cooked veg A) } \\
100 \mathrm{~g} \text { or } 1 \text { cup (cooked veg B) } \\
200 \mathrm{~g} \text { or } 1 \text { cup (cooked veg C) } \\
150 \mathrm{~g} \text { (fruit) } \\
200 \mathrm{~g} \text { or } 1 \text { glass (juice) } \\
\text { Assessed separately } \\
\text { Household measures }\end{array}$ \\
\hline O'Neill et al. ${ }^{(82) *}$ & $\begin{array}{l}\text { Semi-quantitative } \\
\text { 107-item FFQ }\end{array}$ & $\begin{array}{l}\text { Determine and compare } \\
\text { carotenoid intakes } \\
\text { across European } \\
\text { countries }\end{array}$ & $\begin{array}{l}\text { Adults } \\
25 \pm 45 \text { years }\end{array}$ & $\begin{array}{l}\text { Ninety-five items: } \\
\text { Twenty-eight green veg items } \\
\text { (including pulses) } \\
\text { Seventeen red-orange } \\
\text { vegetable items } \\
\text { Seventeen white-yellowish } \\
\text { coloured veg items } \\
\text { (including potatoes) } \\
\text { Twenty-seven individual fruit } \\
\text { items } \\
\text { Six F\&V relevant items under } \\
\text { 'Other products' (mainly } \\
\text { tomato products and soups } \\
\text { and orange juice) }\end{array}$ & Past 3-4 months & Self-admin. & $\begin{array}{l}\text { If high frequency, range from } \\
1 \text { to } 7 \text { per week } \\
\text { If low consumption frequency, } \\
4 \text { categories ranging from } \\
\text { 'never' to 'once per fortnight' }\end{array}$ & $\begin{array}{l}\text { Yes } \\
\text { Assessed separately } \\
\text { Asked to quantify intake for } \\
\text { each food item by } \\
\text { tablespoons for vegetables } \\
\text { and by large, small or } \\
\text { medium in terms for fruit }\end{array}$ \\
\hline $\mathrm{PRIME}^{(84)}$ & $\begin{array}{l}\text { Non-quantitative } \\
\text { No. of items NR }\end{array}$ & $\begin{array}{l}\text { Assess relationship } \\
\text { between F\&V intake and } \\
\text { CVD }\end{array}$ & $\begin{array}{l}\text { Adults/men } \\
50-59 \text { years }\end{array}$ & $\begin{array}{l}\text { Exact classification unknownt } \\
\text { 'Citrus fruit', 'Other fruit', 'Raw } \\
\text { vegetables' 'Baked } \\
\text { vegetables' }\end{array}$ & NR & Self-admin. & $\begin{array}{l}7 \text { categories, ranging from } \\
\text { 'never' to 'more than once } \\
\text { per day' (subject reports } \\
\text { number per day) }\end{array}$ & $\begin{array}{l}\text { Assessed in-line } \\
\text { Frequency of consumption of a } \\
\text { 'standard portion' }\end{array}$ \\
\hline
\end{tabular}


Table 4 Continued

\begin{tabular}{|c|c|c|c|c|c|c|c|c|}
\hline Study & Type/no. of items & Purpose & Population & F\&V items \& classification & Reference period & Mode & Categories & Portion estimation \\
\hline $\begin{array}{l}\text { Finnish and Russian } \\
\text { Karelia study }{ }^{(146) \star} \\
(2002 \text { survey) }\end{array}$ & $\begin{array}{l}\text { Non-quantitative } \\
\text { Forty-three-item } \\
\text { FFQ (FINRISK) } \\
\text { and two-item } \\
\text { FFQ (Pitkaranta } \\
\text { town) within a } \\
\text { general } \\
\text { questionnaire }\end{array}$ & $\begin{array}{l}\text { Determine impact of socio- } \\
\text { economic differences on } \\
\text { consumption of } F \& V \text { and } \\
\text { berries }\end{array}$ & $\begin{array}{l}\text { Adults } \\
25-64 \text { years }\end{array}$ & $\begin{array}{l}\text { Finnish FFQ: } \\
\text { Nine items: } \\
\text { Six 'Vegetables' items } \\
\text { (including pulses, potatoes) } \\
\text { Three 'Fruits/berries' items } \\
\text { Russian FFQ: } \\
\text { Six items: } \\
\text { Four 'Vegetables' items } \\
\text { (including pulses, potatoes) } \\
\text { Two 'Fruits and berries' items }\end{array}$ & 12 months & Self-admin. & $\begin{array}{l}6 \text { categories, ranging from 'less } \\
\text { than once a month' to 'once } \\
\text { a day or more often' }\end{array}$ & No \\
\hline Rylander et al. ${ }^{(88)}$ & $\begin{array}{l}\text { Non-quantitative } \\
\text { Ninety-item FFQ }\end{array}$ & $\begin{array}{l}\text { Test association of dietary } \\
\text { habits and smoking } \\
\text { status }\end{array}$ & $\begin{array}{l}\text { Adults } \\
35-65 \text { years }\end{array}$ & Exact classification unknown† & 12 months & Self-admin. & $\begin{array}{l}10 \text { categories, ranging from } \\
\text { 'never' to 'six or more times } \\
\text { per day' }\end{array}$ & No \\
\hline $\begin{array}{l}\text { ToyBox Caregiver's } \\
\text { Questionnaire } \\
\text { (95-106)* }\end{array}$ & $\begin{array}{l}\text { Semi-quantitative. } \\
\text { Five-item FFQ } \\
\text { (drinking } \\
\text { behaviour) and } \\
\text { fourteen-item } \\
\text { FFQ (snacking } \\
\text { behaviour) } \\
\text { within a general } \\
\text { questionnaire }\end{array}$ & $\begin{array}{l}\text { Measure the effectiveness } \\
\text { of an intervention to } \\
\text { prevent obesity }\end{array}$ & $\begin{array}{l}\text { Adults/caregivers } \\
\text { Age range NR }\end{array}$ & $\begin{array}{l}\text { Three items: } \\
\text { Drinking behaviour: } \\
\text { Examples provided. } \\
\text { 'Fruit juice, home-made, } \\
\text { freshly squeezed' } \\
\text { Snacking behaviour: } \\
\text { 'Fresh fruits' } \\
\text { 'Vegetables' }\end{array}$ & 12 months & Self-admin. & $\begin{array}{l}7 \text { categories, ranging from ' } 1- \\
3 \text { days per month' to 'every } \\
\text { day' }\end{array}$ & $\begin{array}{l}\text { Yes } \\
\text { Assessed in-line } \\
\text { Portion size specified for fruit } \\
\text { juice as beaker }=225 \mathrm{ml} \text {, } \\
1 \text { small plastic bottle } \\
=500 \mathrm{ml}, 1 \text { carton }=1 \text { litre } \\
\text { Aided by a photo book }\end{array}$ \\
\hline MEDIS $^{(78)}$ & $\begin{array}{l}\text { Non-quantitative } \\
\text { No. of items NR }\end{array}$ & $\begin{array}{l}\text { Test association between } \\
\text { energy-generating } \\
\text { nutrients and obesity }\end{array}$ & $\begin{array}{l}\text { Adults/elderly } \\
65-80+\text { years }\end{array}$ & $\begin{array}{l}\text { Exact classification unknown† } \\
\text { 'Fruits',' 'Vegetables', 'Greens } \\
\text { and salads' } \\
\text { Potatoes and legumes } \\
\text { assessed separately }\end{array}$ & NR & NR & $\begin{array}{l}\text { Frequency assessed on a daily, } \\
\text { weekly or monthly basis }\end{array}$ & No \\
\hline Terry et al..(93) & $\begin{array}{l}\text { Semi-quantitative } \\
\text { Dietary } \\
\text { questionnaire } \\
\text { No. of items NR }\end{array}$ & $\begin{array}{l}\text { Test association between } \\
\text { diet and brain tumour } \\
\text { risk }\end{array}$ & $\begin{array}{l}\text { Adults } \\
20-82 \text { years }\end{array}$ & Exact classification unknown† & NR & $\begin{array}{l}\text { Face-to face } \\
\text { interview }\end{array}$ & Exact classification unknown† & $\begin{array}{l}\text { Yes } \\
\text { Assessed separately } \\
\text { Abstract food models or } \\
\text { photographs used to aid } \\
\text { portion size estimation }\end{array}$ \\
\hline Pro-Children ${ }^{(86) *}$ & $\begin{array}{l}\text { Non-quantitative } \\
\text { Six-item FFQ within } \\
\text { a general } \\
\text { questionnaire }\end{array}$ & $\begin{array}{l}\text { Assess F\&V consumption } \\
\text { Identify determinants of } \\
\text { F\&V consumption } \\
\text { patterns }\end{array}$ & $\begin{array}{l}\text { Adults/parents } \\
\text { Age range NR }\end{array}$ & $\begin{array}{l}\text { Six items: } \\
\text { 'Fresh fruit' } \\
\text { 'Salad or grated vegetables' } \\
\text { 'Raw vegetables' } \\
\text { 'Cooked vegetables' } \\
\text { '100\% fruit juice' } \\
\text { Potatoes assessed separately }\end{array}$ & NR & Self-admin. & $\begin{array}{l}8 \text { categories, ranging from } \\
\text { 'never' to 'every day, more } \\
\text { than twice a day' }\end{array}$ & No \\
\hline Kolarzyk et al. ${ }^{(48) \star}$ & $\begin{array}{l}\text { Non-quantitative } \\
\text { Thirty-nine-item } \\
\text { FFQ }\end{array}$ & $\begin{array}{l}\text { Assess diet and the } \\
\text { prevalence of } \\
\text { underweight, overweight } \\
\text { and obesity }\end{array}$ & $\begin{array}{l}\text { Adults/students } \\
\text { Age range NR }\end{array}$ & $\begin{array}{l}\text { Four items: } \\
\text { 'Fruit' } \\
\text { 'Vegetables' } \\
\text { 'Fruit juice' } \\
\text { 'Vegetable juice' } \\
\text { Pulses and potatoes } \\
\text { assessed separately }\end{array}$ & Previous month & Self-admin. & $\begin{array}{l}7 \text { categories, ranging from 'not } \\
\text { eaten at all' to 'eaten every } \\
\text { day' }\end{array}$ & No \\
\hline \multicolumn{9}{|l|}{ Adolescents } \\
\hline Gerrits et al. ${ }^{(109)}$ & $\begin{array}{l}\text { Non-quantitative } \\
\text { Two items within a } \\
\text { general } \\
\text { questionnaire }\end{array}$ & $\begin{array}{l}\text { Test association of } \\
\text { psychological variables } \\
\text { with consumption of fatty } \\
\text { foods and F\&V }\end{array}$ & $\begin{array}{l}\text { Adolescents } \\
14-19 \text { years }\end{array}$ & $\begin{array}{l}\text { Exact classification unknownt } \\
\text { 'Servings of fruit' } \\
\text { 'Servings of vegetables' }\end{array}$ & $\begin{array}{l}\text { Usual consumption } \\
\text { per day }\end{array}$ & Self-admin. & $\begin{array}{l}4 \text { categories, ranging from 'less } \\
\text { than one serving a day' to ' } 3 \\
\text { or more servings a day' }\end{array}$ & $\begin{array}{l}\text { Yes } \\
\text { Assessed in-line } \\
\text { Asked to specify number of } \\
\quad \text { servings }\end{array}$ \\
\hline $\operatorname{HELENA}^{(47,121)}$ & $\begin{array}{l}\text { Semi-quantitative } \\
\text { 137-item FFQ }\end{array}$ & $\begin{array}{l}\text { Assess effectiveness of an } \\
\text { intervention to enhance } \\
\text { the physical activity and } \\
\text { diet of adolescents }\end{array}$ & $\begin{array}{l}\text { Adolescents } \\
13-17 \text { years }\end{array}$ & $\begin{array}{l}\text { Exact classification unknownt } \\
\text { Groups: 'Vegetables' (pulses } \\
\text { included), 'Fruit' } \\
\text { One F\&V juices item } \\
\text { Potatoes assessed separately }\end{array}$ & NR & Self-admin. & $\begin{array}{l}10 \text { categories } \\
\text { Then select frequency of: } \\
\text { 'Units per day', 'Units per } \\
\text { week' or 'Units during the } \\
\text { last } 30 \text { d' }\end{array}$ & $\begin{array}{l}\text { Yes } \\
\text { Assessed in-line } \\
\text { Frequency and portion } \\
\text { selected together for fruit } \\
\text { juices; i.e. } 1 \text { glass/2 glass, } \\
10 \text { glass } \\
\text { Photos, } 4 \text { portion sizes } \\
\text { (amorphous foods) }\end{array}$ \\
\hline
\end{tabular}


Table 4 Continued

\begin{tabular}{|c|c|c|c|c|c|c|c|c|}
\hline Study & Type/no. of items & Purpose & Population & $\mathrm{F} \& \mathrm{~V}$ items \& classification & Reference period & Mode & Categories & Portion estimation \\
\hline TEMPEST $^{(115) *}$ & $\begin{array}{l}\text { Semi-quantitative } \\
\text { Five-item FFQ } \\
\text { within a general } \\
\text { questionnaire }\end{array}$ & $\begin{array}{l}\text { Test association of } \\
\text { 'subjective peer norms' } \\
\text { with eating intentions } \\
\text { and diet }\end{array}$ & $\begin{array}{l}\text { Adolescents } \\
12-17 \text { years }\end{array}$ & $\begin{array}{l}\text { Two items: } \\
\text { 'Fruit' } \\
\text { 'Cooked or raw vegetables' }\end{array}$ & Per average day & Self-admin. & $\begin{array}{l}5 \text { categories, ranging from 'less } \\
\text { than } 1 \text { ' to 'more than } 4 \text { ' }\end{array}$ & $\begin{array}{l}\text { Yes } \\
\text { Assessed in-line } \\
\text { Participants asked to report } \\
\text { 'servings' of fruit or 'serving } \\
\text { spoons' of cooked or raw } \\
\text { vegetables }\end{array}$ \\
\hline HBSC $2009 / 10^{(31,110) *}$ & $\begin{array}{l}\text { Non-quantitative } \\
\text { Four-item FFQ } \\
\text { within general } \\
\text { questionnaire }\end{array}$ & $\begin{array}{l}\text { Determine health and } \\
\text { health behaviours and } \\
\text { the factors that influence } \\
\text { them }{ }^{(31)} \\
\text { Investigate influence of } \\
\text { chronological period of } \\
\text { data collection on } \\
\text { dietary intake } \\
(110)\end{array}$ & $\begin{array}{l}\text { Adolescents } \\
11-, 13-\text { and } 15- \\
\text { year-olds }\end{array}$ & $\begin{array}{l}\text { Two items: } \\
\text { 'Fruits' } \\
\text { 'Vegetables' }\end{array}$ & $\begin{array}{r}\text { Habitual intake } \\
\text { over a week }\end{array}$ & Self-admin. & $\begin{array}{l}7 \text { categories, ranging from } \\
\text { 'never' to 'every day, more } \\
\text { than once' }\end{array}$ & No \\
\hline I.Family Project ${ }^{(50)}$ & $\begin{array}{l}\text { Non-quantitative } \\
\text { Sixty-item FFQ }\end{array}$ & $\begin{array}{l}\text { Assess determinants of } \\
\text { eating behaviour }\end{array}$ & $\begin{array}{l}\text { Adolescents } \\
12-17 \text { years }\end{array}$ & $\begin{array}{l}\text { Nine items: } \\
\text { Four veg items (including } \\
\text { legumes, and potatoes) } \\
\text { Two fruit items (fresh with or } \\
\text { without sugar) } \\
\text { One fruit juice item } \\
\text { Nuts and dried fruits } \\
\text { separately (two items) } \\
\text { under 'snacks' }\end{array}$ & $\begin{array}{l}\text { Typical week over } \\
\text { the previous } \\
\text { month }\end{array}$ & Self admin. & $\begin{array}{l}7 \text { categories, ranging from } \\
\text { 'never/less than once a } \\
\text { week' to ' } 4 \text { or more times } \\
\text { per day' }\end{array}$ & No \\
\hline Szczepanska et al. ${ }^{(114) *}$ & $\begin{array}{l}\text { Non-quantitative } \\
\text { Twelve-item FFQ }\end{array}$ & $\begin{array}{l}\text { Assess and compare } \\
\text { dietary habits }\end{array}$ & $\begin{array}{l}\text { Adolescents } \\
\text { Age range NR }\end{array}$ & $\begin{array}{l}\text { Two items: } \\
\text { 'Fruit' } \\
\text { 'Vegetables' }\end{array}$ & Not stated & Self-admin. & $\begin{array}{l}5 \text { categories, ranging from } \\
\text { 'never' to ' } 3-4 \text { times per } \\
\text { week' }\end{array}$ & No \\
\hline Larsson et al. ${ }^{(113) *}$ & $\begin{array}{l}\text { Non-quantitative } \\
\text { Thirty-three-item } \\
\text { FFQ within a } \\
\text { general } \\
\text { questionnaire }\end{array}$ & $\begin{array}{l}\text { Determine prevalence of } \\
\text { vegetarianism } \\
\text { Compare food habits } \\
\text { among vegetarians and } \\
\text { omnivores }\end{array}$ & $\begin{array}{l}\text { Adolescents } \\
\text { Age range NR }\end{array}$ & $\begin{array}{l}\text { Fifteen items: } \\
\text { 'Vegetables (all except } \\
\text { potatoes)' } \\
\text { Eight vegetable items } \\
\text { 'Fruits and berries (including } \\
\text { frozen)' } \\
\text { Five fruit items } \\
\text { Potatoes assessed separately }\end{array}$ & 12 months & Self-admin. & $\begin{array}{l}6 \text { categories, ranging from } \\
\text { 'never/rarely' to 'several } \\
\text { times a day' }\end{array}$ & No \\
\hline \multicolumn{9}{|l|}{ Children } \\
\hline Antova et al. ${ }^{(116) *}$ & $\begin{array}{l}\text { Non-quantitative } \\
\text { Five-item FFQ } \\
\text { within a general } \\
\text { questionnaire }\end{array}$ & $\begin{array}{l}\text { Test association between } \\
\text { diet and respiratory } \\
\text { health }\end{array}$ & $\begin{array}{l}\text { Children } \\
7-11 \text { years }\end{array}$ & $\begin{array}{l}\text { Two items: } \\
\text { 'Fresh fruit' (in Winter, in } \\
\text { Summer) } \\
\text { 'Fresh vegetables' (in Winter, } \\
\text { in Summer) } \\
\text { F\&V seasonality assessed }\end{array}$ & NR & Self-admin. & $\begin{array}{l}4 \text { categories, ranging from } \\
\text { ' }>4 \text { times per week' to 'less } \\
\text { than once per month' }\end{array}$ & No \\
\hline ENERGY(27)* & $\begin{array}{l}\text { Semi-quantitative } \\
\text { General } \\
\text { questionnaire }\end{array}$ & $\begin{array}{l}\text { Determine prevalence of } \\
\text { EBRB } \\
\text { Identify personal, family } \\
\text { and school } \\
\text { environmental correlates } \\
\text { of EBRB }\end{array}$ & $\begin{array}{l}\text { Children } \\
10-12 \text { years }\end{array}$ & $\begin{array}{l}\text { One item: } \\
\text { Fruit juices. 'When we say } \\
\text { fruit juices we mean the } \\
\text { packed fruit juice and } \\
\text { freshly blended juice at } \\
\text { home ( } 100 \% \text { fruit juice)' } \\
\text { Examples provided }\end{array}$ & $\begin{array}{l}\text { Previous week } \\
\text { Usual consumption } \\
\text { on a day on } \\
\text { which fruit juices } \\
\text { are drunk }\end{array}$ & Self-admin. & $\begin{array}{l}7 \text { categories per week } \\
6 \text { categories per day }\end{array}$ & $\begin{array}{l}\text { Yes } \\
\text { Assessed in-line } \\
\text { Subject can select number of } \\
\text { glasses/small cartons } \\
(250 \mathrm{ml}) \text { and regular cartons } \\
(330 \mathrm{ml}) \text { drank on a day of } \\
\text { consumption }\end{array}$ \\
\hline $\operatorname{IDEFICS}^{(37,118,122)_{\star}}$ & $\begin{array}{l}\text { Non-quantitative } \\
\text { Forty-three-item } \\
\text { FFQ }\end{array}$ & $\begin{array}{l}\text { Determine the aetiology of } \\
\text { overweight, obesity and } \\
\text { related disorders } \\
\text { Test association between } \\
\text { diet and cardiovascular } \\
\text { risk factors } \\
\text { Test }{ }^{(39)} \\
\text { diet ansociation between body mass } \\
\text { di18) }\end{array}$ & $\begin{array}{l}\text { Children } \\
2-9 \text { years } \\
\text { (parents or } \\
\quad \text { guardians as } \\
\text { proxies) }\end{array}$ & $\begin{array}{l}\text { Eight items: } \\
\text { Four vegetable items } \\
\text { (including legumes, and } \\
\text { potatoes) } \\
\text { Two fruit items (fresh with or } \\
\text { without sugar) } \\
\text { One fruit juice item } \\
\text { Nuts and dried fruits } \\
\text { separately under 'snacks' }\end{array}$ & $\begin{array}{l}\text { Typical week over } \\
\text { the previous } \\
\text { month }\end{array}$ & Self-admin. & $\begin{array}{l}8 \text { categories, ranging from } \\
\text { 'never/less than once a } \\
\text { week' to ' } 4 \text { or more times } \\
\text { per day' } \\
\text { 'I have no idea' was also an } \\
\text { option }\end{array}$ & No \\
\hline
\end{tabular}


Table 4 Continued

\begin{tabular}{|c|c|c|c|c|c|c|c|c|}
\hline Study & Type/no. of items & Purpose & Population & F\&V items \& classification & Reference period & Mode & Categories & Portion estimation \\
\hline I.Family Project ${ }^{(50)}$ & $\begin{array}{l}\text { Non-quantitative } \\
\text { Fifty-nine-item FFQ }\end{array}$ & $\begin{array}{l}\text { Assess determinants of } \\
\text { eating behaviour }\end{array}$ & $\begin{array}{l}\text { Children } \\
2-11 \text { years } \\
\text { (parents or } \\
\text { guardians as } \\
\text { proxies) }\end{array}$ & $\begin{array}{l}\text { Eight items: } \\
\text { Four vegetable items } \\
\text { (including legumes, and } \\
\text { potatoes) } \\
\text { Two fruit items (fresh with or } \\
\text { without sugar) } \\
\text { One fruit juice item } \\
\text { Nuts and dried fruits } \\
\text { separately (two items) } \\
\text { under 'snacks' }\end{array}$ & $\begin{array}{l}\text { Typical week over } \\
\text { the previous } \\
\text { month }\end{array}$ & Self admin. & $\begin{array}{l}7 \text { categories, ranging from } \\
\text { 'never/less than once a } \\
\text { week' to ' } 4 \text { or more times } \\
\text { per day' }\end{array}$ & No \\
\hline$I_{S A A C}^{(120) *}$ & $\begin{array}{l}\text { Non-quantitative } \\
\text { Eight-item FFQ } \\
\text { within a general } \\
\text { questionnaire }\end{array}$ & $\begin{array}{l}\text { Test association between } \\
\text { dietary factors, asthma } \\
\text { and allergy }\end{array}$ & $\begin{array}{l}\text { Children } \\
8-12 \text { years } \\
\text { (parents or } \\
\quad \text { guardians) }\end{array}$ & $\begin{array}{l}\text { Four items: } \\
\text { 'Fresh fruit' } \\
\text { 'Raw green vegetables' } \\
\text { 'Cooked green vegetables' } \\
\text { 'Fruit juice' }\end{array}$ & NR & Self-admin. & $\begin{array}{l}5 \text { categories, ranging from } \\
\text { 'never' to 'once per day or } \\
\text { more often' }\end{array}$ & No \\
\hline $\begin{array}{l}\text { Pro-Children/PRO } \\
\text { GREENS }^{(42,85-87,136) *}\end{array}$ & $\begin{array}{l}\text { Non-quantitative } \\
\text { Six-item FFQ within } \\
\text { a general } \\
\text { questionnaire }\end{array}$ & $\begin{array}{l}\text { Assess F\&V consumption } \\
\text { and determinants of } \\
F \& V \text { consumption } \\
\text { patterns }\end{array}$ & $\begin{array}{l}\text { Children } \\
11 \text { years }\end{array}$ & $\begin{array}{l}\text { Five items: } \\
\text { 'Fresh fruit' } \\
\text { 'Salad or grated vegetables' } \\
\text { 'Raw vegetables' } \\
\text { 'Cooked vegetables' } \\
\text { '100\% fruit juice' } \\
\text { Potatoes assessed separately }\end{array}$ & NR & Self-admin. & $\begin{array}{l}8 \text { categories, ranging from } \\
\text { 'never' to 'every day, more } \\
\text { than twice a day' }\end{array}$ & No \\
\hline $\begin{array}{l}\text { ToyBox Children's } \\
\text { FFQ }^{(95-106) \star}\end{array}$ & $\begin{array}{l}\text { Semi-quantitative } \\
\text { Forty-four-item } \\
\text { FFQ }\end{array}$ & $\begin{array}{l}\text { Measure the effectiveness } \\
\text { of an intervention to } \\
\text { prevent obesity }\end{array}$ & $\begin{array}{l}\text { Children } \\
3.5-5.5 \text { years } \\
\text { (parents or } \\
\quad \text { guardians as } \\
\text { proxies) }\end{array}$ & $\begin{array}{l}\text { Six items: } \\
\text { 'Fruit juice, home-made, } \\
\text { freshly squeezed' } \\
\text { Global groups used: 'Dried } \\
\text { fruit',, 'Canned fruit',, 'Fresh } \\
\text { fruit', 'Raw veg' and } \\
\text { 'Cooked veg' } \\
\text { Potatoes and legumes } \\
\text { assessed separately }\end{array}$ & 12 months & Self-admin. & $\begin{array}{l}6 \text { categories, ranging from } \\
\text { '1-3 days per month' to } \\
\text { 'every day' }\end{array}$ & $\begin{array}{l}\text { Yes } \\
\text { Assessed separately } \\
\text { Subjects asked to select from a } \\
\text { range of portion for each } \\
\text { food, e.g. from ' '100 ml or } \\
\text { less' to ' } 1000 \mathrm{ml} \text { or more'. } \\
\text { Examples of corresponding } \\
\text { portions (g or ml) provided } \\
\text { for each food item } \\
\text { Photo book in appendix of the } \\
\text { FFQ }\end{array}$ \\
\hline
\end{tabular}

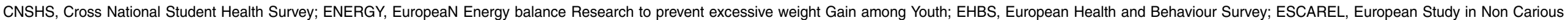

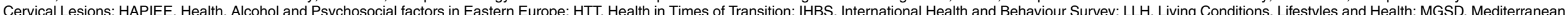

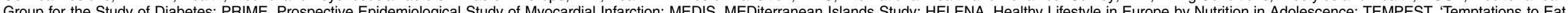

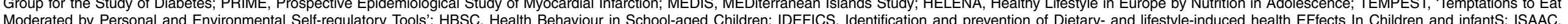

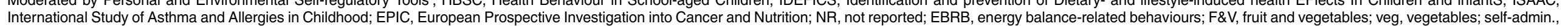
self-administered; CATI, computer-assisted telephone interview; PAPI, paper-assisted personal interview.

${ }^{*}$ Original instrument obtained for review.

tOriginal instrument not obtained.

łInformation on Food4Me instrument was obtained from study authors. 
size using photographs ${ }^{(30,36,39,50,52,53,93,95-99,101,102,104-106)}$, absolute weights ${ }^{(39)}$ or household measures ${ }^{(36,39,79)}$. Fruit was often estimated in natural units or standard portions (e.g. one piece, one fruit $\left.{ }^{(82)}\right)$. Other FFQ asked participants to record the quantity eaten for each food item either in tablespoons for vegetables (unless otherwise indicated as florets, slices, etc.) or by small, medium and large for fruit ${ }^{(82)}$. The ToyBox Children's FFQ asked participants to select from a pre-coded list of portion size ranges for each separate food item, providing examples of typical food items corresponding to these measurements (e.g. 1 tablespoon of prepared vegetables $=30 \mathrm{~g}$ ). The ENERGY questionnaire asked participants to report the number of glasses or small bottles, cans and/or bottles, and specified volumes for each.

Some FFQ recorded portion size in-line; that is, participants were asked to report the frequency of a named portion ${ }^{(54,56,69,79,84,100,109,115)}$. The Willett FFQ used by Baldini et al. ${ }^{(54)}$ provided a detailed description of what constitutes a usual serving size for each of the $120 \mathrm{FFQ}$ items and the MGSD (Mediterranean Group for the Study of Diabetes) $\mathrm{FFQ}^{(79)}$ outlined the usual serving size for different food categories (i.e. one serving of raw vegetables constitutes $100 \mathrm{~g}$ or about $1 \mathrm{cup}$ ).

\section{Diet records/diet diaries}

The characteristics of the identified diet records are summarised in Table 5. Diet records were typically used to determine and compare estimates of dietary intake across regions.

Seven pan-European studies ${ }^{(44,46,68,81,83,92,94)}$ used diet records or diaries, either a $7 \mathrm{~d}$ record or three consecutive day records. With the exception of studies which used weighed records $^{(83)}$ or a mixed approach ${ }^{(81)}$, most studies estimated portion size using photographs ${ }^{(30,46,91)}$, household measures and objects (e.g. cups, spoons, etc. $)^{(30,44,46)}$, standard units ${ }^{(46)}$ or an artificial model of foods ${ }^{(46,91)}$. Participants were typically asked to record a description of the food eaten, the time and location at which it was eaten, an estimated portion, the preparation method, brand names (or, if possible, recipe details), and weights or amounts of leftovers $^{(83)}$. A few records were pre-coded or structured ${ }^{(46,108)}$.

\section{Dietary history method}

The other method identified (Table 5) was the cross-check dietary history method used as part of the Seven Countries Study. Food consumption recorded at each meal occasion was used to generate a list of foods. This list was then used to assess consumption of each food on a daily, weekly or monthly basis. Tessier et al. ${ }^{(94)}$ used a qualitative diet history method to record present diet in comparison with past diet. This was largely open-ended but included a frequency scale for vegetable consumption.

\section{Dietary recalls}

Characteristics of the identified 24-HDR are summarised in Table 6. The majority of the 24-HDR were used to determine estimates of dietary intake, comparing estimates across regions or over time. Among the nine studies which used the $24-H D R$ method $^{(28,30,35,38,55,74,77,86,107)}$, five were computerised methods. Two were conducted via face-toface interview (i.e. SACINA and EPIC) and three were selfadministered (i.e. HELENA, SACANA child and SACANA adult 24-HDR). There were six paper-based methods. Both the IDEFICS and I.Family 24-HDR programs, SACINA ${ }^{(38)}$ and SACANA ${ }^{(50)}$, and the program used by the HELENA study, HELENA-DIAT ${ }^{(35)}$, were based on the YANA-C (Young Adolescents' Nutrition Assessment on Computer) and structured by six meals/times throughout the day. Information was entered directly into the program, with the exception of the Hungary centre where participants completed the 24-HDR at home, after which the data were entered. EPIC-SOFT differed in that before foods were entered per meal, a 'quick list' of all food and recipes consumed during that day was entered by an interviewer in chronological order, with each quick list item described and quantified.

All four computer-based 24-HDR incorporated prompts and reminders, including probes and warnings for data exceeding normal ranges; checked entries for occurrence of fruit, vegetables and sweets; or probed for food items often eaten in combination with other items ${ }^{(34,35)}$ or displayed checklists containing foods easily forgotten ${ }^{(28)}$. The remaining 24-HDR were conducted via face-to-face interview and incorporated different levels of structure, pre-coding and prompts, including listing some items so that participants were specifically prompted to think about their consumption of different fruits, vegetables and juices ${ }^{(96,131)}$. Portion size was assessed largely using photographs $^{(28,35,38,55,87)}$, household measures ${ }^{(55,77)}$, drawings of commonly used foods ${ }^{(55)}$ or standard measures (i.e. cups).

\section{Discussion}

The aim of the current review was to identify the main methods used to assess intake of $\mathrm{F} \& \mathrm{~V}$ in pan-European studies that measured dietary intake of F\&V (FFQ, $n$ 42; 24-HDR, $n$ 11; diet record/diet diary/dietary history, $n 7$ ). Of the identified methods, forty-one were used to assess intake among adults, five of which assessed intake among parents/caregivers. Nine assessed intake among children ranging in age from 2 to 12 years, and seven were used among adolescents. Key differences were found to exist between methods to measure intake of F\&V, which should be considered in terms of how they might affect the comprehensiveness, and the comparability, of the intake data collected. For example, the identified FFQ differed in many respects, some of which have been reported previously $^{(152,153)}$. These included: (i) listing individual fruits or vegetables $v$. non-itemised, broad terms; (ii) including potatoes and legumes under the heading of 
Table 5 Summary of diet records: instrument purpose and characteristics

\begin{tabular}{|c|c|c|c|c|c|c|}
\hline Study & Population & Purpose & Time period & Mode & Structure & Portion estimation \\
\hline $\begin{array}{l}\text { 'Food in later life' } \\
\text { project }^{(68)}\end{array}$ & $\begin{array}{l}\text { Adults/elderly } \\
65-98 \text { years }\end{array}$ & $\begin{array}{l}\text { Identify factors associated } \\
\text { with nutritional risk }\end{array}$ & $\begin{array}{l}\text { Seven } \\
\text { consecutive } \\
\text { days }\end{array}$ & Self-admin. & None reported & Estimated \\
\hline $\begin{array}{l}\text { North/South Food } \\
\text { Consumption } \\
\text { survey }{ }^{(45,81)}\end{array}$ & $\begin{array}{l}\text { Adults } \\
18-64 \text { years }\end{array}$ & $\begin{array}{l}\text { Determine estimates of } \\
\text { intake of dietary fibre and } \\
\text { NSP(81) } \\
\text { Establish a database of } \\
\text { habitual food and drink } \\
\text { consumption } \\
(45)\end{array}$ & $\begin{array}{l}\text { Seven } \\
\text { consecutive } \\
\text { days }\end{array}$ & Self-admin. & $\begin{array}{l}\text { Recorded the types and amounts of all foods, } \\
\text { beverages and nutritional supplements, the time } \\
\text { and location of each 'eating occasion', the } \\
\text { method of cooking and brand name, leftovers, } \\
\text { recipe details and a definition of the 'eating } \\
\text { occasion' as the subject perceived it, as either a } \\
\text { meal or a snack } \\
\text { Detailed instructions were given on the recording of } \\
\text { recipes and food/drink eaten out }\end{array}$ & $\begin{array}{l}\text { Mixed methods: } \\
\text { Direct weighing, photographic atlas and food } \\
\text { manufacturers' product data, IUNA information } \\
\text { and data from previous UK surveys. The foods } \\
\text { selected for inclusion in the album for use in the } \\
\text { survey were foods consumed commonly in } \\
\text { Ireland } \\
\text { Portion was 'estimated' if the fieldworker made an } \\
\text { assessment of the amount likely to have been } \\
\text { consumed, based on their knowledge of the } \\
\text { respondent's general eating habits observed } \\
\text { during the recording period } \\
\text { IUNA information: } \\
\text { Average portions were ascertained for certain } \\
\text { foods by the survey team. These foods included } \\
\text { fruits, vegetables } \\
\text { Data collected as part of previous UK studies: } \\
\text { These included weights of vegetables }\end{array}$ \\
\hline Parfitt et al. ${ }^{(83)}$ & $\begin{array}{l}\text { Adults } \\
18-32 \text { years }\end{array}$ & $\begin{array}{l}\text { Compare dietary intake in } \\
\text { persons on typical regional } \\
\text { diets }\end{array}$ & $\begin{array}{l}5-7 \mathrm{~d} \\
\text { (not reported if } \\
\text { consecutive) }\end{array}$ & Self-admin. & None reported & $\begin{array}{l}\text { Estimated and weighed } \\
\text { All portions eaten and component ingredients, } \\
\text { where relevant, were weighed on household } \\
\text { scales } \\
\text { Meals eaten out portions quantified in household } \\
\text { measures or the standard reference work Food } \\
\text { Portion Sizes ' } 17 \text { ' was used to help estimate } \\
\text { portion sizes }\end{array}$ \\
\hline $\operatorname{SENECA}^{(43,44,90)}$ & $\begin{array}{l}\text { Adults/elderly } \\
70-75 \text { years }\end{array}$ & $\begin{array}{l}\text { Examine cross-cultural } \\
\text { differences in nutrition and } \\
\text { lifestyle factors }{ }^{(43)} \\
\text { Examine cross-cultural } \\
\text { variations and changes in } \\
\text { intake over time }\end{array}$ & $\begin{array}{l}\text { Three } \\
\text { consecutive } \\
\text { days }\end{array}$ & $\begin{array}{l}\text { Self-admin. ( } 3 \text { d record) } \\
\text { followed by face-to- } \\
\text { face interview }\end{array}$ & $\begin{array}{l}\text { 1. Estimated diet record, structured by } 8 \text { meal } \\
\text { periods } \\
\text { 2. Frequency checklist } \\
\text { Relevant items on Dutch frequency checklist } \\
\text { included: } \\
\text { Under vegetables: } \\
\text { 'Green leafy vegetables', 'Carrots', 'Tomatoes', } \\
\text { 'Pulses', 'Peppers', 'Potatoes',' 'Other beans } \\
\text { and peas', 'Other beets/roots', 'Salads' } \\
\text { Under fruits: } \\
\text { 'Fruits rich in vit. C \& examples', 'Bananas', } \\
\text { 'Carotene rich fruit \& examples', 'Dried fruits', } \\
\text { 'Fatty fruits', 'Other fruits' }\end{array}$ & $\begin{array}{l}\text { Estimated and weighed } \\
\text { Portion sizes recorded in household measures and } \\
\text { checked by weighing } \\
\text { Beverages portion size estimated using glasses or } \\
\text { cups }\end{array}$ \\
\hline
\end{tabular}


Table 5 Continued

\begin{tabular}{|c|c|c|c|c|c|c|}
\hline Study & Population & Purpose & Time period & Mode & Structure & Portion estimation \\
\hline $\begin{array}{l}\text { Seven Countries } \\
\text { Study }^{(4,91,92)}\end{array}$ & $\begin{array}{l}\text { Adults/elderly } \\
40-59 \text { years (at } \\
\text { enrolment) }\end{array}$ & $\begin{array}{l}\text { Compare diets among } \\
\text { diabetic and non-diabetic } \\
\text { men }^{(91)} \\
\text { Test association of F\&V and } \\
\text { fish with COPD } \\
(4,92)\end{array}$ & $\begin{array}{l}\text { Cross-check } \\
\text { dietary history } \\
\text { Method } \\
\text { concerning the } \\
\text { month } \\
\text { preceding the } \\
\text { interview }\end{array}$ & Face-to-face interview & $\begin{array}{l}\text { Usual food consumption pattern of a person was } \\
\text { assessed on daily basis during week and } \\
\text { weekend days, i.e. about the foods used at } \\
\text { breakfast, lunch, dinner and between meals. } \\
\text { Based on list of all food compiled from this, they } \\
\text { recorded what was eaten on a daily, weekly or } \\
\text { monthly basis } \\
\text { Checklist with an extensive number of foods was } \\
\text { used to record the frequencies and amounts of } \\
\text { foods consumed }\end{array}$ & $\begin{array}{l}\text { Estimated } \\
\text { Finland: photos } \\
\text { The Netherlands: by a portable scale } \\
\text { Italy: by artificial models of different foods in Italy }\end{array}$ \\
\hline Tessier et al. ${ }^{(94) \star ~}$ & $\begin{array}{l}\text { Adults/mothers } \\
50-91 \text { years } \\
\text { Adults/daughters } \\
22-60 \text { years }\end{array}$ & $\begin{array}{l}\text { Examine changes in diet } \\
\text { intake over time }\end{array}$ & $\begin{array}{l}\text { Qualitative } \\
\text { questionnaire. } \\
\text { Not stated }\end{array}$ & Face-to-face interview & $\begin{array}{l}\text { Open-ended questions. Four-category frequency } \\
\text { scale for vegetables: never; rarely; sometimes; } \\
\text { often; always }\end{array}$ & No \\
\hline $\begin{array}{l}\text { WHO-MONICA EC/ } \\
\text { MONICA Project } \\
\text { optional nutrition } \\
\text { study }^{(46,108,123)}\end{array}$ & $\begin{array}{l}\text { Adults/men } \\
45-64 \text { years }\end{array}$ & $\begin{array}{l}\text { Monitor trends in risk factors } \\
\text { for CVD, including diet(108) } \\
\text { Assess snack patterns } \\
(123)\end{array}$ & $\begin{array}{l}\text { Three } \\
\text { consecutive } \\
\text { days (Belgium, } \\
\text { France, } \\
\text { Northern } \\
\text { Ireland, } \\
\text { Finland, Italy) } \\
\text { Seven } \\
\text { consecutive } \\
\text { days (Germany, } \\
\text { Denmark, UK) } \\
\text { Three } \\
\text { consecutive } \\
\text { 24-HDR } \\
\text { (Barcelona) }\end{array}$ & $\begin{array}{l}\text { Self-admin. } \\
\text { Interview-administered } \\
\text { or telephone- } \\
\text { administered for } \\
\text { Barcelona }\end{array}$ & $\begin{array}{l}\text { Generally week and weekend days representative } \\
\text { for the whole week were included } \\
\text { Data collection in several seasons } \\
\text { Recorded preparation method, type of food or } \\
\text { brand names, and recipes }\end{array}$ & $\begin{array}{l}\text { Estimated } \\
\text { Picture book/food models (France, Spain, Italy, } \\
\text { Germany) } \\
\text { Household measures (Germany, France, Spain, } \\
\text { Finland, UK, Italy, Denmark) } \\
\text { Standard units (Germany, France, Finland, Spain, } \\
\text { UK, Italy, Denmark) }\end{array}$ \\
\hline
\end{tabular}

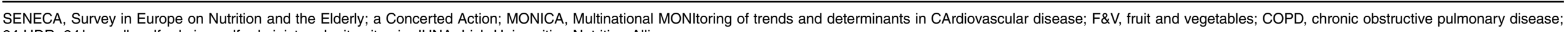

24-HDR, $24 \mathrm{~h}$ recall; self-admin., self-administered, vit., vitamin; IUNA, Irish Universities Nutrition Alliance. 
Table 6 Summary of dietary recalls: instrument purpose and characteristics

\begin{tabular}{|c|c|c|c|c|c|c|}
\hline Study & Population & Purpose & Method of adminsitration & Structure & Prompts & Portion estimation \\
\hline \\
\hline $\mathrm{EPIC}^{(28,63)}$ & $\begin{array}{l}\text { Adults } \\
30-70 \text { years }\end{array}$ & $\begin{array}{l}\text { Provide comparable food } \\
\text { consumption data between } \\
\text { several European countries }\end{array}$ & $\begin{array}{l}\text { EPIC-SOFT } \\
1 \times 24-\mathrm{HDR} \\
\text { Computerised, face-to-face } \\
\text { interview }\end{array}$ & $\begin{array}{l}\text { 1. 'Quick list' chronological entry of all } \\
\text { foods and recipes consumed during day } \\
\text { 2. Foods are entered per meal } \\
\text { 3. Each 'quick list' item is described and } \\
\text { quantified }\end{array}$ & $\begin{array}{l}\text { Yes. Program mediated } \\
\text { Checklist of foods easily } \\
\text { forgotten is displayed on } \\
\text { screen }\end{array}$ & $\begin{array}{l}\text { Estimated } \\
\text { Six quantification methods including } \\
\text { photos ( } 2-6 \text { portion sizes), shapes, } \\
\text { household measurements, standard } \\
\text { units, standard portions, volume method } \\
\text { and 'unknown' method }\end{array}$ \\
\hline Baltic project ${ }^{(55)}$ & $\begin{array}{l}\text { Adults } \\
19-65 \text { years }\end{array}$ & $\begin{array}{l}\text { Assess macronutrient and diet } \\
\text { intakes including } \mathrm{F} \& \mathrm{~V} \\
\text { consumption }\end{array}$ & $\begin{array}{l}1 \times 24-H D R \\
\text { Interview-administered }\end{array}$ & Not indicated & NR & $\begin{array}{l}\text { Estimated } \\
\text { Household measures and photographs and/ } \\
\text { or drawings of commonly used foods }\end{array}$ \\
\hline Van Diepen et al. ${ }^{(107)}$ & $\begin{array}{l}\text { Adults } \\
\text { Age range NR }\end{array}$ & $\begin{array}{l}\text { Assess and compare } \\
\text { Mediterranean diet } \\
\text { adherence }\end{array}$ & $\begin{array}{l}\text { Two consecutive 24-HDR } \\
\text { Mode NR }\end{array}$ & NR & NR & NR \\
\hline LiVicordia $^{(77)}$ & $\begin{array}{l}\text { Adults/men } \\
50 \text { years old }\end{array}$ & $\begin{array}{l}\text { Assess and compare mean } \\
\text { estimates of food intake }\end{array}$ & $\begin{array}{l}1 \times 24-\mathrm{HDR} \\
\text { Face-to-face interview }\end{array}$ & $\begin{array}{l}\text { Open-ended } \\
\text { Used a checklist for 'Between meals' } \\
\text { consumption which included 'Fruit } \\
\text { (apples, bananas)' }\end{array}$ & Yes & $\begin{array}{l}\text { Estimated } \\
\text { Household measures; } 1,5,15 \text { and } 100 \mathrm{ml} \text {; } \\
\text { a ruler; packages of butter and } \\
\text { margarine } 5 \text { and } 10 \mathrm{~g} \text {; and glass with } \\
150 \mathrm{ml} \text { water }\end{array}$ \\
\hline $\begin{array}{l}\text { I.Family Project }{ }^{(50,74)} \\
\text { SACANA }\end{array}$ & $\begin{array}{l}\text { Adults/parents } \\
\text { No age range } \\
\text { determined }\end{array}$ & $\begin{array}{l}\text { Identify determinants of food } \\
\text { choice, lifestyle and health }\end{array}$ & $\begin{array}{l}1 \times 24-\mathrm{HDR} \\
\text { Computerised, self-admin. }\end{array}$ & $\begin{array}{l}\text { Meal occasions, one breakfast, one lunch, } \\
\text { one dinner; snacks and drinks as needed }\end{array}$ & Yes. Program mediated & $\begin{array}{l}\text { Accurate portion size in } \mathrm{g} \text { or } \mathrm{ml} \text { and } \\
\text { graphical images and photos }\end{array}$ \\
\hline $\begin{array}{l}\text { Pro-Children (42,86,87,136)*/ } \\
\text { PRO GREENS }{ }^{(85)}\end{array}$ & Adults/parents & $\begin{array}{l}\text { Assess } F \& V \text { consumption and } \\
\text { determinants of } F \& V \\
\text { consumption patterns }\end{array}$ & $\begin{array}{l}1 \times 24-\mathrm{HDR} \\
\text { Self-admin. }\end{array}$ & $\begin{array}{l}6 \text { time intervals } \\
\text { 'Did you eat or drink anything yesterday } \\
\text { morning? (yes/no)'.' 'What was it?' } \\
\text { Pre-coded with some fruit and vegetables } \\
\text { items and asked e.g. 'Did you eat fruit } \\
\text { yesterday morning?' }\end{array}$ & NR & $\begin{array}{l}\text { Estimated } \\
\text { Photos, } 3 \text { portion sizes (for salad, for } \\
\text { cooked vegetables and for fruit salad) } \\
\text { Asked to report amounts in terms of the } \\
\text { number of pieces, slices or portions } \\
\text { eaten, e.g. number of pieces of fruit }\end{array}$ \\
\hline $\begin{array}{l}\text { Adolescents } \\
\text { HELENA }^{(34,35)}\end{array}$ & $\begin{array}{l}\text { Adolescents } \\
13-17 \text { years }\end{array}$ & Assess food and nutrient intake & $\begin{array}{l}\text { HELENA-DIAT } \\
\text { Two non-consecutive 24-HDR } \\
\text { (within } 2 \text { weeks) } \\
\text { Computerised, self-admin. }\end{array}$ & 6 meal occasions & $\begin{array}{l}\text { Yes. Program mediated } \\
\text { Checked entries for occurrence } \\
\text { of fruit, vegetables and } \\
\text { sweets and asked 'if really } \\
\text { not consumed' } \\
\text { Probed for foods commonly } \\
\text { eaten in conjunction with } \\
\text { others }\end{array}$ & $\begin{array}{l}\text { Estimated } \\
\text { Photos } \\
\text { Several measurement units (e.g. spoon, } \\
\text { can, glass, grams, etc.) used and, if } \\
\text { suitable, more than one measurement } \\
\text { unit is present for the same food item }\end{array}$ \\
\hline $\begin{array}{l}\text { Children } \\
\text { EYHS } \\
\text { (Based on copy of } \\
\text { Danish 'Kostkema', i.e. } \\
\text { may not be same as } \\
\text { Swedish 24-HDR) }\end{array}$ & $\begin{array}{l}\text { Children } \\
9 \text { and } 15 \text { years }\end{array}$ & $\begin{array}{l}\text { Examine personal, } \\
\text { environmental, and lifestyle } \\
\text { influences on cardiovascular } \\
\text { risk factors } \\
\text { Examine changes in diet intake } \\
\text { over time }^{(117)}\end{array}$ & $\begin{array}{l}1 \times 24-\mathrm{HDR} \\
\text { Face-to-face interview }\end{array}$ & $\begin{array}{l}\text { 24-HDR preceded by a } 1 \mathrm{~d} \text { qualitative, } \\
\text { parent-assisted food record the previous } \\
\text { day } \\
\text { 24-HDR food checklist and recorded the } \\
\text { type, description of food and location } \\
\text { where eaten }\end{array}$ & Yes, during interview & $\begin{array}{l}\text { Estimated } \\
\text { Different-sized drinking glasses, plates, } \\
\text { spoons and food pictures of most } \\
\text { common foods and food groups in } \\
\text { different portion sizes were used to } \\
\text { estimate food quantities }\end{array}$ \\
\hline IDEFICS $^{(37,119,135)}$ & $\begin{array}{l}\text { Children } \\
2-9 \text { years (parents or } \\
\quad \text { guardians as } \\
\text { proxies) }\end{array}$ & $\begin{array}{l}\text { Determine the aetiology of } \\
\text { overweight, obesity and } \\
\text { related disorder }\end{array}$ & $\begin{array}{l}\text { SACINA } \\
1 \times 24-\mathrm{HDR} \\
\text { Computerised, face-to-face } \\
\text { interview } \\
\text { Hungary: self-admin. 24-HDR } \\
\text { at home }\end{array}$ & 6 meal occasions & Yes. Program mediated & $\begin{array}{l}\text { Estimated } \\
\text { Photos }\end{array}$ \\
\hline $\begin{array}{l}\text { Pro-Children } \\
\text { PRO GREENS }{ }^{(25), 86,87,136)} /\end{array}$ & $\begin{array}{l}\text { Children } \\
11 \text { years }\end{array}$ & $\begin{array}{l}\text { Assess } F \& V \text { consumption and } \\
\text { determinants of } F \& V \\
\text { consumption patterns }\end{array}$ & $\begin{array}{l}1 \times 24-\mathrm{HDR} \\
\text { Self-admin. }\end{array}$ & $\begin{array}{l}6 \text { time intervals } \\
\text { 'Did you eat or drink anything yesterday } \\
\text { morning? (yes/no)'. 'What was it?' } \\
\text { Pre-coded with some fruit and vegetables } \\
\text { items and asked e.g. 'Did you eat fruit } \\
\text { yesterday morning?' }\end{array}$ & NR & $\begin{array}{l}\text { Estimated } \\
\text { Photos, three portion sizes (for salad, for } \\
\text { cooked vegetables and for fruit salad) } \\
\text { Asked to report amounts in terms of the } \\
\text { number of pieces, slices or portions } \\
\text { eaten, e.g. number of pieces of fruit }\end{array}$ \\
\hline
\end{tabular}

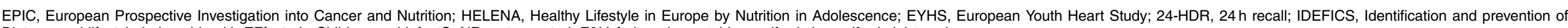
Dietary- and lifestyle-induced health EFfects In Children and infantS; NR, not reported; F\&V, fruit and vegetables; self-admin., self-administered.

${ }^{*}$ Original instrument obtained for review. 
vegetables; (iii) variation in the number and range of items (from about twenty to forty specific items to fewer than five broad items); (iv) variation in the number and range of frequency categories; and (v) variation in the method of portion size estimation.

While dietary assessment methods used in $\mathrm{US}^{(156)}$ or $\mathrm{UK}^{(157)}$ studies have previously been compiled, the current review is the first to specifically focus on systematically identifying and describing instruments that can be used to assess intake of F\&V in pan-European studies. As European-wide interventions to promote the consumption of $\mathrm{F} \& \mathrm{~V}$ are further developed, valid instruments that can assess and monitor intake in a standardised and comparable way across Europe are essential. In order to identify instruments which would be most promising to use in future pan-European studies to measure $\mathrm{F} \& \mathrm{~V}$, and those to include in the DEDIPAC toolbox, two selection criteria were applied: (i) the instrument was tested for validity and/or reproducibility; and (ii) the instrument was used in more than two countries simultaneously which represented a range of European regions.

According to these criteria, six instruments appear to be suitable to assess intake of $\mathrm{F} \& \mathrm{~V}$ among adults in pan-European studies. However, only two of the studies had been validated for F\&V intake (EPIC-SOFT and Food $4 \mathrm{Me}$ ), using biomarkers and $4 \mathrm{~d}$ diet records, respectively. All three instruments selected to assess intake among adolescents, the HELENA-DIAT instrument, the HELENA online FFQ and the HBSC FFQ, had been validated, using 24-HDR (HELENA instruments) and both 24-HDR and $7 \mathrm{~d}$ diet record (HBSC) as reference methods, with good agreement but some overestimation of intakes by the HELENA and HBSC FFQ. Five instruments were selected to assess intake among children; however, just three instruments were validated for F\&V intake (IDEFICS FFQ, Pro-Children and ToyBox), using 24-HDR (IDEFICS), $7 \mathrm{~d}$ (Pro-Children) and $3 \mathrm{~d}$ (ToyBox) diet records as the reference method, demonstrating moderately good ranking for food groups by the Pro-Children instrument, moderate relative validity for ToyBox and low agreement of the IDEFICS FFQ with 24-HDR.

As already stated, the results of the current review will feed into the development of the DEDIPAC toolbox of dietary intake assessment methods, which will provide a basis for appraising and selecting suitable instruments for use in future pan-European studies. However, before selecting from the eight validated instruments shortlisted herein, the quality of the validity and/or reproducibility studies performed for the instrument should be considered to assess the suitability of the instruments identified for the study in question; for example, judging the reference method used (i.e. biomarkers, long-term or shortterm dietary assessment method) and the statistics used to assess validity (i.e. whether compared at group level, mean/median differences, or assessed using crude, energy-adjusted, de-attenuated or intraclass correlations) ${ }^{(156)}$. Although a tool may have been tested for validity in several countries, ideally it should be validated in the population in which it is to be used. Although no selection was made based on the comprehensiveness of the instrument, this may be another criterion to consider before utilising the instrument in question; that is, based on the cut-off of five items used by Cook et al. ${ }^{(151)}$, the ENERGY parent and child instruments, the ToyBox parent's questionnaire and the HBSC FFQ were ranked as having low comprehensiveness for F\&V.

The purpose of the dietary assessment should also be taken into consideration. Most of the identified FFQ were used to identify determinants of dietary intake or examine diet-disease associations. This contrasts with 24-HDR and diet records, which were primarily used to assess intake for cross-cultural comparisons or over time. It is generally accepted $^{(153)}$ that diet records, 24-HDR and dietary history methods, unlike FFQ, are suitable for cross-cultural comparisons. FFQ are typically designed to be populationspecific, encapsulating local dietary customs and foods, and may not be the ideal instrument to use across several countries $^{(153)}$. However, this also must be balanced against the feasibility of using the instrument; namely, resourcedemanding methods such as interview-administered 24-HDR (EPIC-SOFT) compared with self-completed 24-HDR (HELENA-DIAT) or FFQ (Food4Me, IDEFICS, HBSC, HELENA, Pro-Children and ToyBox instruments), which needs to be taken into consideration to determine whether an instrument can be used effectively to assess intake of $\mathrm{F} \& \mathrm{~V}$ in a chosen pan-European population.

Owing to the lack of an appraisal tool to rate dietary assessment instruments on the basis of their characteristics, the quality of the identified instruments was not assessed as part of the current review. Future work should consider developing a standardised approach to appraisal which would greatly aid any comparison of quality across dietary assessment tools, particularly where validation studies are absent. Comparing the characteristics of the instruments identified in the current review could provide a basis for agreement on such quality standards; for example, requiring instruments to assess portion size and, where they do, that a consistent approach be used defining servings in units which are understandable to participants (e.g. ' $15 \mathrm{~g}$ or tablespoon' of cooked vegetables, 'beaker $=225 \mathrm{ml}$ ' of fruit juice) or through use of a standardised photographic food atlas.

It may also be possible to decide how specific FFQ questions, including the format of these questions, could be better standardised across FFQ used in pan-European studies, even if the FFQ themselves are country-specific. As highlighted, the identified FFQ varied considerably on comprehensiveness (number of items) and detail (use of broad terms like 'fruit' or 'vegetables' $v$. specific items). While cut-offs such as that used by Cook et al. ${ }^{(151)}$ may be applied, any judgement on comprehensiveness must be balanced against the purpose of the assessment; for 
example, is the aim is to examine dietary patterns overall, rather than focus specifically on health and disease associations with individual fruits and vegetables, and is there additional benefit to be gained from providing an exhaustive list? However, where broad terms are included, this needs to be supplemented with adequate explanation or an inventory of items intended to fall under these terms, to avoid the possibility of participant misunderstanding and consequently variation across countries and regions. For example, some FFQ listed fruit or vegetable juice but did not always specify $100 \%$ fruit or vegetable juice. Similarly, some did not clarify whether potatoes or legumes were covered by a broader term such as 'vegetables'.

The current review has a number of strengths and limits. A comprehensive search strategy was used that aimed to identify all pan-European studies measuring the intake of F\&V among children and adults, and their associated assessment instruments. The search was supplemented by hand-searching reference lists, sourcing further instruments through contact with study authors, and reviewing the results of concurrently occurring systematic literature reviews. Where possible, a copy of the original instrument was obtained to facilitate the description of the methods. However, although a comprehensive search was conducted, the possibility that all relevant articles were not identified cannot be excluded. The review is limited in its focus to pan-European studies, as the aim was to identify instruments used in European populations and to provide a selection of methods which may be applied to future studies based in these countries. However, this does not preclude the fact that additional instruments and innovative methods ${ }^{(157)}$ that have been used and validated as part of large-scale nonEuropean studies, such as the US NHANES (National Health and Nutrition Examination Survey) ${ }^{(158)}$, may be suitable for assessing intakes across Europe. In some cases, a copy of the original instrument or article that detailed characteristics of the assessment method could not be identified and the description provided may be limited as a result. This being said, the primary aim of the review was to identify assessment instruments. Therefore the results serve as a valuable reference. As mentioned, no quality appraisal of the identified instruments could be conducted. However, by indicating which instruments were validated and/or tested for reproducibility, summarising these results and applying additional criteria, the review has selected a number of potential instruments and provided a basis for determining the suitability of instruments for use in future studies.

\section{Conclusion}

The present review has identified a range of instruments to assess intake of F\&V and indicates that a large degree of variability exists between currently available instruments. To standardise the measurement of F\&V intake between European countries, instruments should use a consistent approach to assessing $\mathrm{F} \& \mathrm{~V}$; for example, using itemised terms and, when non-itemised broad terms are used, clarifying whether potatoes and legumes/pulses are captured by these terms. The current review has indicated eight instruments validated for $F \& V$ intake that may be suitable to assess the intake of F\&V among adult, child or adolescent populations. These methods have been used in pan-European populations, encompassing a range of European regions, and should be considered for use by future studies focused on evaluating consumption of F\&V.

\section{Acknowledgements}

Financial support: The preparation of this paper was supported by the DEDIPAC Knowledge Hub. This work was supported by the Joint Programming Initiative 'Healthy Diet for a Healthy Life'. The funding agency supporting this work was The Health Research Board (HRB), Ireland (DEDIPAC/2013/1). Conflict of interest: L.F.A. was coauthor on the Pro-Children validity and reproducibility study. Authorship: F.R. planned and conducted the review, and drafted and revised the paper. K.R. planned and conducted the review, and drafted the paper. I.J.P. drafted and revised the paper. M.B.S. contributed to the planning, and drafted and revised the paper. L.F.A. contributed to the planning, and drafted and revised the paper. A.G. drafted and revised the paper. P.v.V. drafted and revised the paper. S.E. conducted the review of validation data, and drafted and revised the paper. P.D. conducted the review of validation data, and drafted and revised the paper. N.W.-D. conducted the review of validation data, and drafted and revised the paper. J.M.H. contributed to the planning, and drafted and revised the paper. Ethics of buman subject participation: Not applicable.

\section{Supplementary material}

To view supplementary material for this article, please visit http://dx.doi.org/10.1017/S1368980016002366

\section{References}

1. Aburto NJ, Ziolkovska A, Hooper L et al. (2013) Effect of lower sodium intake on health: systematic review and meta-analyses. BMJ 346, f1326.

2. Hanson C, Rutten EP, Wouters EF et al. (2013) Diet and vitamin $\mathrm{D}$ as risk factors for lung impairment and COPD. Transl Res 162, 219-236.

3. World Health Organization (2003) Diet, Nutrition and the Prevention of Chronic Diseases. Joint WHO/FAO Expert Consultation. WHO Technical Report Series no. 916. Geneva: WHO.

4. Walda IC, Tabak C, Smit HA et al. (2002) Diet and 20-year chronic obstructive pulmonary disease mortality in middle-aged men from three European countries. Eur J Clin Nutr 56, 638-643. 
5. Cecchini M, Sassi F, Lauer JA et al. (2010) Tackling of unhealthy diets, physical inactivity, and obesity: health effects and cost-effectiveness. Lancet 376, 1775-1784.

6. Dauchet L, Amouyel P, Hercberg S et al. (2006) Fruit and vegetable consumption and risk of coronary heart disease: a meta-analysis of cohort studies. J Nutr 136, 2588-2593.

7. Joshipura KJ, Hu FB, Manson JE et al. (2001) The effect of fruit and vegetable intake on risk for coronary heart disease. Ann Intern Med 134, 1106-1114.

8. Waxman A (2004) WHO global strategy on diet, physical activity and health. Food Nutr Bull 25, 292-302.

9. Food and Agriculture Organization of the United Nations \& World Health Organization (2004) Fruit and Vegetables for Health: Report of a Joint FAO/WHO Workshop, 1-3 September 2004, Kobe, Japan. Geneva: WHO.

10. Agudo A (2005) Measuring Intake of Fruit and Vegetables. Background Paper for the Joint FAO/WHO Workshop on Fruit and Vegetables for Health, 1-3 September 2004, Kobe, Japan. Barcelona: Unit of Epidemiology, Catalan Institute of Oncology.

11. Blanquer M, Garcia-Alvarez A, Ribas-Barba L et al. (2009) How to find information on national food and nutrient consumption surveys across Europe: systematic literature review and questionnaires to selected country experts are both good strategies. Br J Nutr 101, Suppl. 2, S37-S50.

12. Roark RA \& Niederhauser VP (2013) Fruit and vegetable intake: issues with definition and measurement. Public Health Nutr 16, 2-7.

13. National and Kapodistrian University of Athens (2014) DAFNE. Data Food Networking. http://www.nut.uoa.gr/ dafnesoftweb/ (accessed September 2014).

14. Norfoods project (2014) A Nordic approach to Food Composition Data. http://www.fooddata.dk/norfoods/? Nordic_food_data (accessed September 2014).

15. Castenmiller J \& West CE (1995) Report of the Third Annual FLAIR-Eurofoods-Enfant Project Meeting, Vilamoura, Portugal, 1993. Wageningen: FLAIREurofoods-Enfant Project (1994).

16. Working Group on Food Data Management and Interchange (2000) COST Action 99. Research Action on Food Consumption and Composition Data. Eurofoods Recommendations for Food Composition Database Management and Data Interchange. Luxembourg: Office for Official Publications of the European Communities.

17. EFCOSUM Group (2001) European Food Consumption Survey Method. Final Report. TNO Report no. V3766. Zeist: TNO Nutrition and Food Research.

18. Riboli E \& Kaaks R (1997) The EPIC Project: rationale and study design. European Prospective Investigation into Cancer and Nutrition. Int J Epidemiol 26, Suppl. 1, S6-S14.

19. Innovative Dietary Assessment Methods in Epidemiological Studies and Public Health (2010) Dietary Assessment Methods: State of the Art Report. Potsdam-Rehbrücke: German Institute of Human Nutrition (DIfE).

20. European Food Safety Authority (2009) General principles for the collection of national food consumption data in the view of a pan-European dietary survey. EFSA J 7, 1435.

21. European Food Safety Authority (2014) Guidance on the EU Menu methodology. EFSA J 12, 3944.

22. Determinants of Diet and Physical Activity Knowledge Hub (2014) Home page. https://www.dedipac.eu/ (accessed September 2014).

23. Lakerveld J, van der Ploeg H, Kroeze W et al. (2014) Towards the integration and development of a crossEuropean research network and infrastructure: the DEterminants of DIet and Physical ACtivity (DEDIPAC) Knowledge Hub. Int J Behav Nutr Phys Act 11, 143.

24. Harrington JM, Riordan F \& Ryan K (2014) What are the assessment methods used to determine dietary intake of fruit and vegetables in adults ( $>18$ years) and children in European countries, according to pan-European studies involving two or more European countries? http://www. crd.york.ac.uk/PROSPERO/display_record.asp?ID=CRD 42 014012947 (accessed August 2016).

25. Council of Europe (2014) 47 Member States. http:// www.coe.int/en/web/portal/47-members-states (accessed September 2014).

26. United Nations (2014) Composition of macro geographical (continental) regions, geographical sub-regions, and selected economic and other groupings. http://unstats.un. org/unsd/methods/m49/m49regin.htm (accessed March 2014).

27. van Stralen MM, te Velde SJ, Singh AS et al. (2011) EuropeaN Energy balance Research to prevent excessive weight Gain among Youth (ENERGY) project: design and methodology of the ENERGY cross-sectional survey. BMC Public Health 11, 65.

28. Slimani N, Deharveng G, Charrondiere RU et al. (1999) Structure of the standardized computerized 24-h diet recall interview used as reference method in the 22 centers participating in the EPIC project. European Prospective Investigation into Cancer and Nutrition. Comput Methods Programs Biomed 58, 251-266.

29. Riboli E, Hunt KJ, Slimani N et al. (2002) European Prospective Investigation into Cancer and Nutrition (EPIC): study populations and data collection. Public Health Nutr 5, 1113-1124.

30. Riddoch C, Edwards D, Page A et al. (2005) The European Youth Heart Study - cardiovascular disease risk factors in children: rationale, aims, study design, and validation of methods. J Phys Act Health 2, 115-129.

31. Currie C, Griebler R, Inchley J et al. (2010) Health Behaviour in School-Aged Children (HBSC) Study Protocol: Background, Methodology and Mandatory Items for the 2009/10 Survey. Edinburgh/Vienna: CAHRU/LBIHPR.

32. Moreno LA, De Henauw S, Gonzalez-Gross M et al. (2008) Design and implementation of the Healthy Lifestyle in Europe by Nutrition in Adolescence Cross-Sectional Study. Int J Obes (Lond) 32, Suppl. 5, S4-S11.

33. Moreno LA, Gonzalez-Gross M, Kersting M et al. (2008) Assessing, understanding and modifying nutritional status, eating habits and physical activity in European adolescents: the HELENA (Healthy Lifestyle in Europe by Nutrition in Adolescence) Study. Public Health Nutr 11, 288-299.

34. Vereecken CA, Covents M, Matthys C et al. (2005) Young adolescents' nutrition assessment on computer (YANA-C). Eur J Clin Nutr 59, 658-667.

35. Vereecken CA, Covents M, Sichert-Hellert W et al. (2008) Development and evaluation of a self-administered computerized 24-h dietary recall method for adolescents in Europe. Int J Obes (Lond) 32, Suppl. 5, S26-S34.

36. Vereecken CA, De Bourdeaudhuij I, Maes L et al. (2010) The HELENA online food frequency questionnaire: reproducibility and comparison with four 24-h recalls in Belgian-Flemish adolescents. Eur J Clin Nutr 64, 541-548.

37. Ahrens W, Bammann K, Siani A et al. (2011) The IDEFICS cohort: design, characteristics and participation in the baseline survey. Int J Obes (Lond) 35, Suppl. 1, S3-S15.

38. Bel-Serrat S, Mouratidou T, Pala V et al. (2014) Relative validity of the Children's Eating Habits Questionnairefood frequency section among young European children: the IDEFICS Study. Public Health Nutr 17, 266-276.

39. van Dongen MC, Lentjes MA, Wijckmans NE et al. (2011) Validation of a food-frequency questionnaire for Flemish and Italian-native subjects in Belgium: the IMMIDIET study. Nutrition 27, 302-309.

40. Weiland SK, Bjorksten B, Brunekreef B et al. (2004) Phase II of the International Study of Asthma and Allergies in 
Childhood (ISAAC II): rationale and methods. Eur Respir J 24, 406-412.

41. Nordic Council of Ministers (2003) The NORBAGREEN 2002 Study. Consumption of Vegetables, Potatoes, Fruit, Bread and Fish in the Nordic and Baltic countries. Contract no. TemaNord 2003:556. Århus: Nordic Council of Ministers.

42. Haraldsdottir J, Thorsdottir I, de Almeida MDV et al. (2005) Validity and reproducibility of a precoded questionnaire to assess fruit and vegetable intake in European 11- to 12-year-old schoolchildren. Ann Nutr Metab 49, 221-227.

43. de Groot LC, Hautvast JG \& van Staveren WA (1992) Nutrition and health of elderly people in Europe: the EURONUT-SENECA Study. Nutr Rev 50, 185-194.

44. de Groot CPGM \& van Staveren WA (1988) Nutrition and the Elderly. A European Collaborative Study in Cooperation with the World Health Organization (WHO-SPRA) and the International Union of Nutritional Sciences (IUNS) Committee on Geriatric Nutrition. Manual of Operations. EURONUT Report no. 11. Wageningen: EURONUT.

45. Harrington KE, Robson PJ, Kiely M et al. (2001) The North/ South Ireland Food Consumption Survey: survey design and methodology. Public Health Nutr 4, 1037-1042.

46. Haveman-Nies A, Bokje E, Ocke M et al. (2003) MONICA Optional Study on Nutrition: The Dietary Assessment Methodology. Bilthoven: RIVM.

47. Maes L, Cook TL, Ottovaere C et al. (2011) Pilot evaluation of the HELENA (Healthy Lifestyle in Europe by Nutrition in Adolescence) Food-O-Meter, a computer-tailored nutrition advice for adolescents: a study in six European cities. Public Health Nutr 14, 1292-1302.

48. Kolarzyk E, Shpakou A, Kleszczewska E et al. (2012) Nutritional status and food choices among first year medical students. Central Eur J Med 7, 396-408.

49. Hebestreit A, Eiben G, Reineke A et al. (c.2014) Computer based 24 HDR Dietary Recall: the SACINA program (draft). Bremen Institue for Prevention Research and Social Medicine (BIPS), University of Bremen, Bremen, Germany; Department of Public Health and Community Medicine, Goteborg University, Sweden; Department of Public Health, Faculty of Medicine and Health Sciences, Ghent University, Belgium.

50. I.Family (2014) Home page. http://www.ifamilystudy.eu/ (accessed September 2014).

51. Celis-Morales C, Livingstone KM, Marsaux CF et al. (2015) Design and baseline characteristics of the Food4Me study: a web-based randomised controlled trial of personalised nutrition in seven European countries. Genes Nutr 10, 450.

52. Forster H, Fallaize R, Gallagher C et al. (2014) Online dietary intake estimation: the Food4Me food frequency questionnaire. J Med Internet Res 16, e150.

53. Fallaize R, Forster H, Macready AL et al. (2014) Online dietary intake estimation: reproducibility and validity of the Food4Me food frequency questionnaire against a 4-day weighed food record. J Med Internet Res 16, e190.

54. Baldini M, Pasqui F, Bordoni A et al. (2009) Is the Mediterranean lifestyle still a reality? Evaluation of food consumption and energy expenditure in Italian and Spanish university students. Public Health Nutr 12, 148-155.

55. Pomerleau J, McKee M, Robertson A et al. (2001) Macronutrient and food intake in the Baltic republics. Eur J Clin Nutr 55, 200-207.

56. Behanova M, Nagyova I, Katreniakova Z et al. (2014) Health-risk behaviours in deprived urban neighbourhoods: a comparison between Slovak and Dutch cities. Int J Public Health 59, 405-414.

57. El Ansari W, Stock C \& Mikolajczyk RT (2012) Relationships between food consumption and living arrangements among university students in four European countries a cross-sectional study. Nutr J 11, 28.

58. Mikolajczyk RT, El Ansari W \& Maxwell AE (2009) Food consumption frequency and perceived stress and depressive symptoms among students in three European countries. Nutr J 8, 31.

59. Hooper R, Heinrich J, Omenaas E et al. (2010) Dietary patterns and risk of asthma: results from three countries in European Community Respiratory Health Survey-II. Br J Nutr 103, 1354-1365.

60. Steptoe A \& Wardle J (2001) Locus of control and health behaviour revisited: a multivariate analysis of young adults from 18 countries. Br J Psychol 92, 659-672.

61. Vrieling A, Verhage BAJ, Van Duijnhoven FJB et al. (2009) Fruit and vegetable consumption and pancreatic cancer risk in the European Prospective Investigation into Cancer and Nutrition. Int J Cancer 124, 1926-1934.

62. Agudo A, Slimani N, Ocke MC et al. (2002) Consumption of vegetables, fruit and other plant foods in the European Prospective Investigation into Cancer and Nutrition (EPIC) cohorts from 10 European countries. Public Health Nutr $\mathbf{5}$, 1179-1196.

63. Crispim SP, Geelen A, Souverein OW et al. (2011) Biomarker-based evaluation of two 24-h recalls for comparing usual fish, fruit and vegetable intakes across European centers in the EFCOVAL Study. Eur J Clin Nutr 65, Suppl. 1, S38-S47.

64. Bartlett DW, Lussi A, West NX et al. (2013) Prevalence of tooth wear on buccal and lingual surfaces and possible risk factors in young European adults. J Dent $\mathbf{4 1}$, 1007-1013.

65. Esteve J, Riboli E, Pequignot G et al. (1996) Diet and cancers of the larynx and hypopharynx: the IARC multicenter study in southwestern Europe. Cancer Causes Control 7, 240-252.

66. Prattala R, Paalanen L, Grinberga D et al. (2007) Gender differences in the consumption of meat, fruit and vegetables are similar in Finland and the Baltic countries. Eur J Public Health 17, 520-525.

67. Paalanen L, Prattala R, Alfthan G et al. (2014) Vegetable and fruit consumption, education and plasma vitamin $\mathrm{C}$ concentration in Russian and Finnish Karelia, 1992-2002. Public Health Nutr 17, 2278-2286.

68. de Morais C, Oliveira B, Afonso C et al. (2013) Nutritional risk of European elderly. Eur J Clin Nutr 67, 1215-1219.

69. Galanti MR, Hansson L, Bergstrom R et al. (1997) Diet and the risk of papillary and follicular thyroid carcinoma: a population-based case-control study in Sweden and Norway. Cancer Causes Control 8, 205-214.

70. Boylan S, Welch A, Pikhart H et al. (2009) Dietary habits in three Central and Eastern European countries: the HAPIEE study. BMC Public Health 9, 439.

71. Abe SK, Stickley A, Roberts B et al. (2013) Changing patterns of fruit and vegetable intake in countries of the former Soviet Union. Public Health Nutr 16, 1924-1932.

72. Hupkens CLH, Knibbe RA \& Drop MJ (1997) Social class differences in women's fat and fibre consumption: a crossnational study. Appetite 28, 131-149.

73. Determinants of eating behaviour in European children, adolescents and their parents (I.Family) (2012-2017) Diet Questionnaire. EC FP7 Grant Agreement no. 266044.

74. Determinants of eating behaviour in European children, adolescents and their parents (I.Family) (2012-2017) SACANA. EC FP7 Grant Agreement no. 266044.

75. Grant N, Wardle J \& Steptoe A (2009) The relationship between life satisfaction and health behavior: a crosscultural analysis of young adults. Int J Behav Med 16, 259-268.

76. Pounis G, de Lorgeril M, Salen P et al. (2014) Dietary patterns and fatty acids levels of three European 
populations. Results from the IMMIDIET study. Nutr Metab Cardiovasc Dis 24, 883-890.

77. Elwing B, Kullberg C, Kucinskiene Z et al. (2001) A comparative study of food intake between Lithuanian and Swedish middle-aged men: the LiVicordia study. Scand J Nutr/Naringsforskning 45, 126-130.

78. Tyrovolas S, Psaltopoulou T, Pounis G et al. (2011) Nutrient intake in relation to central and overall obesity status among elderly people living in the Mediterranean islands: the MEDIS study. Nutr Metab Cardiovasc Dis 21, 438-445.

79. Karamanos B, Thanopoulou A, Angelico F et al. (2002) Nutritional habits in the Mediterranean Basin. The macronutrient composition of diet and its relation with the tradiational Mediterranean diet. Multi-centre study of the Mediterranean Group for the study of diabetes (MGSD). Eur J Clin Nutr 56, 983-991.

80. Petkeviciene J, Simila M, Becker W et al. (2009) Validity and reproducibility of the NORBAGREEN food frequency questionnaire. Eur J Clin Nutr 63, 141-149.

81. Galvin M, Kiely M, Harrington K et al. (2001) The North/ South Ireland Food Consumption Survey: the dietary fibre intake of Irish adults. Public Health Nutr $\mathbf{4}$, 1061-1068.

82. O'Neill ME, Carroll Y, Corridan B et al. (2001) A European carotenoid database to assess carotenoid intakes and its use in a five-country comparative study. Br J Nutr $\mathbf{8 5}$, 499-507.

83. Parfitt VJ, Rubba P, Bolton C et al. (1994) A comparison of antioxidant status and free radical peroxidation of plasma lipoproteins in healthy young persons from Naples and Bristol. Eur Heart J 15, 871-876.

84. Dauchet L, Ferrieres J, Arveiler D et al. (2004) Frequency of fruit and vegetable consumption and coronary heart disease in France and Northern Ireland: the PRIME study. Br J Nutr 92, 963-972.

85. Lehto E, Ray C, Te Velde S et al. (2015) Mediation of parental educational level on fruit and vegetable intake among schoolchildren in ten European countries. Public Health Nutr 18, 89-99.

86. Klepp KI, Perez-Rodrigo C, De Bourdeaudhuij I et al. (2005) Promoting fruit and vegetable consumption among European schoolchildren: rationale, conceptualization and design of the Pro Children Project. Ann Nutr Metab 49, 212-220.

87. Yngve A, Wolf A, Poortvliet E et al. (2005) Fruit and vegetable intake in a sample of 11 -year-old children in 9 European countries: the Pro Children crosssectional survey. Ann Nutr Metab 49, 236-245.

88. Rylander R, Axelsson G, Megevand Y et al. (1999) Dietary habits for non-smoking females living with smokers or non-smokers. Eur J Public Health 9, 142-145.

89. Nes M, van Staveren WA, Zajkas G et al. (1991) Validity of the dietary history method in elderly subjects. Euronut SENECA investigators. Eur J Clin Nutr 45, Suppl. 3, 97-104.

90. Schroll K, Moreiras-Varela O, Schlettwein-Gsell D et al. (1997) Cross-cultural variations and changes in food-group intake among elderly women in Europe: results from the Survey in Europe on Nutrition and the Elderly a Concerted Action (SENECA). Am J Clin Nutr 65, 4 Suppl., S1282-S1289.

91. Virtanen SM, Feskens EJM, Rasanen L et al. (2000) Comparison of diets of diabetic and non-diabetic elderly men in Finland, The Netherlands and Italy. Eur J Clin Nutr 54, 181-186.

92. Tabak C, Feskens EJM, Heederik D et al. (1998) Fruit and fish consumption: a possible explanation for population differences in COPD mortality (The Seven Countries Study). Eur J Clin Nutr 52, 819-825.
93. Terry MB, Howe G, Pogoda JM et al. (2009) An international case-control study of adult diet and brain tumor risk: a histology-specific analysis by food group. Ann Epidemiol 19, 161-171.

94. Tessier S \& Gerber M (2005) Factors determining the nutrition transition in two Mediterranean islands: Sardinia and Malta. Public Health Nutr 8, 1286-1292.

95. Androutsos O, Apostolidou E, Iotova V et al. (2014) Process evaluation design and tools used in a kindergarten-based, family-involved intervention to prevent obesity in early childhood. The ToyBox-study. Obes Rev 15, 74-80.

96. Androutsos O, Katsarou C, Payr A et al. (2014) Designing and implementing teachers' training sessions in a kindergarten-based, family-involved intervention to prevent obesity in early childhood. The ToyBox-study. Obes Rev 15, 48-52.

97. De Craemer M, De Decker E, De Bourdeaudhuij I et al. (2014) Applying the Intervention Mapping protocol to develop a kindergarten-based, family-involved intervention to increase European preschool children's physical activity levels: the ToyBox-study. Obes Rev 15, $14-26$.

98. De Miguel-Etayo P, Mesana MI, Cardon G et al. (2014) Reliability of anthropometric measurements in European preschool children: the ToyBox-study. Obes Rev 15, Suppl. 3, 67-73.

99. Duvinage K, Ibrügger S, Kreichauf S et al. (2014) Developing the intervention material to increase physical activity levels of European preschool children: the ToyBox-study. Obes Rev 15, Suppl. 3, 27-39.

100. Gonzalez-Gil EM, Mouratidou T, Cardon G et al. (2014) Reliability of primary caregivers reports on lifestyle behaviours of European pre-school children: the ToyBox-study. Obes Rev 15, Suppl. 3, 61-66.

101. Manios Y, Androutsos O, Katsarou C et al. (2014) Designing and implementing a kindergarten-based, family-involved intervention to prevent obesity in early childhood: the ToyBox-study. Obes Rev 15, Suppl. 3, $5-13$.

102. Manios Y \& ToyBox-study Group (2014) Methodological procedures followed in a kindergarten-based, familyinvolved intervention implemented in six European countries to prevent obesity in early childhood: the ToyBox-study. Obes Rev 15, Suppl. 3, 1-4.

103. Moreno L, Mouratidou T, DeMiguel-Etayo P et al. (2013) Pre-school children's food intake and snacking habits and their determinants. Ann Nutr Metab 63, 65-66.

104. Mouratidou T, Miguel ML, Androutsos O et al. (2014) Tools, harmonization and standardization procedures of the impact and outcome evaluation indices obtained during a kindergarten-based, family-involved intervention to prevent obesity in early childhood: the ToyBox-study. Obes Rev 15, Suppl. 3, 53-60.

105. Payr A, Birnbaum J, Wildgruber A et al. (2014) Concepts and strategies on how to train and motivate teachers to implement a kindergarten-based, family-involved intervention to prevent obesity in early childhood. The ToyBox-study. Obes Rev 15, Suppl. 3, 40-47.

106. Pil L, Putman K, Cardon G et al. (2014) Establishing a method to estimate the cost-effectiveness of a kindergarten-based, family-involved intervention to prevent obesity in early childhood. The ToyBox-study. Obes Rev 15, Suppl. 3, 81-89.

107. Van Diepen S, Scholten AM, Korobili C et al. (2011) Greater Mediterranean diet adherence is observed in Dutch compared with Greek university students. Nutr Metab Cardiovasc Dis 21, 534-540.

108. Evans AE, Ruidavets JB, McCrum EE et al. (1995) Autres pays, autres coeurs? Dietary patterns, risk factors and 
ischaemic heart disease in Belfast and Toulouse. $Q J M \mathbf{8 8}$, 469-477.

109. Gerrits JH, O'Hara RE, Piko BF et al. (2010) Self-control, diet concerns and eater prototypes influence fatty foods consumption of adolescents in three countries. Health Educ Res 25, 1031-1041.

110. Zaborskis A, Moceviciene R \& Iannotti RJ (2014) The influence of chronological period of data collection on differences in reported dietary intake among school-aged children surveyed in 39 countries. J Nutr Educ Behav 46, 359-369.

111. Diethelm K, Jankovic N, Moreno LA et al. (2012) Food intake of European adolescents in the light of different food-based dietary guidelines: results of the HELENA (Healthy Lifestyle in Europe by Nutrition in Adolescence) Study. Public Health Nutr 15, 386-398.

112. Vandevijvere S, Geelen A, Gonzalez-Gross M et al. (2013) Evaluation of food and nutrient intake assessment using concentration biomarkers in European adolescents from the Healthy Lifestyle in Europe by Nutrition in Adolescence study. Br J Nutr 109, 736-747.

113. Larsson CL, Klock KS, Astrom AN et al. (2001) Food habits of young Swedish and Norwegian vegetarians and omnivores. Public Health Nutr 4, 1005-1014.

114. Szczepanska E, Deka M \& Calyniuk B (2013) Studies to determine nutrition behaviour amongst middle school pupils living in the border areas of Poland and the Czech Republic. Rocz Panstw Zakl Hig 64, 191-196.

115. Stok FM, de Vet E, de Wit JB et al. (2015) The proof is in the eating: subjective peer norms are associated with adolescents' eating behaviour. Public Health Nutr 18, 1044-1051.

116. Antova T, Pattenden S, Nikiforov B et al. (2003) Nutrition and respiratory health in children in six Central and Eastern European countries. Thorax 58, 231-236.

117. Patterson E, Warnberg J, Kearney J et al. (2009) The tracking of dietary intakes of children and adolescents in Sweden over six years: the European Youth Heart Study. Int J Behav Nutr Phys Act 6, 91.

118. Pala V, Lissner L, Hebestreit A et al. (2013) Dietary patterns and longitudinal change in body mass in European children: a follow-up study on the IDEFICS multicenter cohort. Eur J Clin Nutr 67, 1042-1049.

119. Bornhorst C, Huybrechts I, Hebestreit A et al. (2013) Dietobesity associations in children: approaches to counteract attenuation caused by misreporting. Public Health Nutr 16, 256-266.

120. Nagel G, Weinmayr G, Kleiner A et al. (2010) Effect of diet on asthma and allergic sensitisation in the international study on allergies and asthma in childhood (ISAAC) phase two. Thorax $\mathbf{6 5}, 516-522$.

121. Vereecken C, Covents M \& Maes L (2010) Comparison of a food frequency questionnaire with an online dietary assessment tool for assessing preschool children's dietary intake. J Hum Nutr Diet 23, 502-510.

122. Bel-Serrat S, Mouratidou T, Santaliestra-Pasias AM et al. (2013) Clustering of multiple lifestyle behaviours and its association to cardiovascular risk factors in children: the IDEFICS study. Eur J Clin Nutr 67, 848-854.

123. Haveman-Nies A, De Groot LCPGM \& Van Staveren WA (1998) Snack patterns of older Europeans. J Am Diet Assoc 98, 1297-1302.

124. Martin-Moreno JM, Boyle P, Gorgojo L et al. (1993) Development and validation of a food frequency questionnaire in Spain. Int J Epidemiol 22, 512-519.

125. Bohlscheid-Thomas S, Hoting I, Boeing H et al. (1997) Reproducibility and relative validity of food group intake in a food frequency questionnaire developed for the German part of the EPIC project. European Prospective Investigation into Cancer and Nutrition. Int J Epidemiol 26, Suppl. 1, S59-S70.
126. Brunner E, Stallone D, Juneja M et al. (2001) Dietary assessment in Whitehall II: comparison of $7 \mathrm{~d}$ diet diary and food-frequency questionnaire and validity against biomarkers. Br J Nutr 86, 405-414.

127. Willett WC, Sampson L, Stampfer MJ et al. (1985) Reproducibility and validity of a semiquantitative food frequency questionnaire. Am J Epidemiol 122, 51-65.

128. Goldbohm RA, van den Brandt PA, Brants HA et al. (1994) Validation of a dietary questionnaire used in a large-scale prospective cohort study on diet and cancer. Eur J Clin Nutr 48, 253-265.

129. Brinkman MT, Kellen E, Zeegers MP et al. (2011) Validation of the IMMIDIET food frequency questionnaire in an adult Belgian population: a report from the Belgian casecontrol study on bladder cancer risk. Acta Clin Belg 66 , $18-25$.

130. Kristjansdottir AG, Andersen LF, Haraldsdottir J et al. (2006) Validity of a questionnaire to assess fruit and vegetable intake in adults. Eur J Clin Nutr 60, 408-415.

131. Bloemberg BP, Kromhout D, Obermann-De Boer GL et al. (1989) The reproducibility of dietary intake data assessed with the cross-check dietary history method. Am J Epidemiol 130, 1047-1056.

132. Vereecken CA \& Maes L (2003) A Belgian study on the reliability and relative validity of the Health Behaviour in School-Aged Children food-frequency questionnaire. Public Health Nutr 6, 581-588.

133. Singh AS, Vik FN, Chinapaw MJM et al. (2011) Test-retest reliability and construct validity of the ENERGY-child questionnaire on energy balance-related behaviours and their potential determinants: the ENERGY-project. Int $J$ Behav Nutr Phys Act 8, 136.

134. Bornhorst C, Bel-Serrat S, Pigeot I et al. (2014) Validity of 24-h recalls in (pre-)school aged children: comparison of proxy-reported energy intakes with measured energy expenditure. Clin Nutr 33, 79-84.

135. Bel-Serrat S, Fernandez Alvira JM, Pala V et al. (2011) Relative validation of two dietary assessment methods: SACINA (24-h recall) and food frequency questionnaire. In 1st IDEFICS Symposium and Workshop Child Health in Europe - The IDEFICS Study: Towards a Better Understanding of Obesity; 2010, Nov 8-9; Zaragoza, Spain. Int J Obes (Lond) 35, Suppl. 1, S152 (abstract).

136. de Bourdeaudhuij I, Klepp KI, Due P et al. (2005) Reliability and validity of a questionnaire to measure personal, social and environmental correlates of fruit and vegetable intake in 10-11-year-old children in five European countries. Public Health Nutr 8, 189-200.

137. Huybrechts I, De Backer G, De Bacquer D et al. (2009) Relative validity and reproducibility of a food-frequency questionnaire for estimating food intakes among Flemish preschoolers. Int J Environ Res Public Health 6, 382-399.

138. Tyrovolas S, Pounis G, Bountziouka V et al. (2010) Repeatability and validation of a short, semi-quantitative food frequency questionnaire designed for older adults living in Mediterranean areas: the MEDIS-FFQ. J Nutr Elder 29, 311-324.

139. Bel-Serrat S, Mouratidou T, Bornhorst C et al. (2013) Food consumption and cardiovascular risk factors in European children: the IDEFICS study. Pediatr Obes 8, 225-236.

140. Huybrechts I, Bornhorst C, Pala V et al. (2011) Evaluation of the Children's Eating Habits Questionnaire used in the IDEFICS study by relating urinary calcium and potassium to milk consumption frequencies among European children. Int J Obes (Lond) 35, Suppl. 1, S69-S78.

141. Bingham SA, Gill C, Welch A et al. (1997) Validation of dietary assessment methods in the UK arm of EPIC using weighed records, and 24-hour urinary nitrogen and potassium and serum vitamin $\mathrm{C}$ and carotenoids as biomarkers. Int J Epidemiol 26, Suppl. 1, S137-S151. 
142. Steptoe A \& Wardle J (1996) The European Health and Behaviour Survey: the development of an international study in health psychology. Psychol Health 11, 49-73.

143. Pisani P, Faggiano F, Krogh V et al. (1997) Relative validity and reproducibility of a food frequency dietary questionnaire for use in the Italian EPIC centres. Int J Epidemiol 26, Suppl. 1, S152-S160.

144. Lytle LA, Nichaman MZ, Obarzanek E et al. (1993) Validation of 24-hour recalls assisted by food records in thirdgrade children. The CATCH Collaborative Group. J Am Diet Assoc 93, 1431-1436.

145. Lanfer A, Hebestreit A, Ahrens W et al. (2011) Reproducibility of food consumption frequencies derived from the Children's Eating Habits Questionnaire used in the IDEFICS study. Int J Obes (Lond) 35, Suppl. 1, S61-S68.

146. Paalanen L, Prattala R, Palosuo H et al. (2011) Socioeconomic differences in the consumption of vegetables, fruit and berries in Russian and Finnish Karelia: 1992-2007. Eur J Public Health 21, 35-42.

147. Boylan S, Lallukka T, Lahelma E et al. (2011) Socioeconomic circumstances and food habits in Eastern, Central and Western European populations. Public Health Nutr 14, 678-687.

148. de Groot LC, Verheijden MW, de Henauw S et al. (2004) Lifestyle, nutritional status, health, and mortality in elderly people across Europe: a review of the longitudinal results of the SENECA study. J Gerontol A Biol Sci Med Sci 59, $1277-1284$.

149. van Staveren WA, de Groot LC, Burema J et al. (1995) Energy balance and health in SENECA participants. Survey in Europe on Nutrition and the Elderly, a Concerted Action. Proc Nutr Soc 54, 617-629.
150. Peasey A, Bobak M, Kubinova R et al. (2006) Determinants of cardiovascular disease and other non-communicable diseases in Central and Eastern Europe: rationale and design of the HAPIEE study. BMC Public Health 6, 255.

151. Cook LT, O'Reilly GA, Derosa CJ et al. (2015) Association between home availability and vegetable consumption in youth: a review. Public Health Nutr 18, 640-648.

152. Cade J, Thompson R, Burley V et al. (2002) Development, validation and utilisation of food-frequency questionnaires - a review. Public Health Nutr 5, 567-587.

153. Thompson FE \& Subar AF (2001) Dietary assessment methodology. In Nutrition in the Prevention and Treatment of Disease, pp. 3-30 [M Ferruzzi, AM Coulston and C Boushy, editors]. San Diego, CA: Academic Press.

154. National Cancer Institute (2016) Dietary Assessment Research Resources. http://epi.grants.cancer.gov/dietaryassessment/resources.html\#methods (accessed August 2016).

155. Wrieden W, Peace H, Armstrong J et al. (2003) A short review of dietary assessment methods used in national and Scottish research studies. Briefing Paper prepared for the Working Group on Monitoring Scottish Dietary Targets Workshop, September 2003.

156. Serra-Majem L, Frost Andersen L, Henrique-Sanchez P et al. (2009) Evaluating the quality of dietary intake validation studies. Br J Nutr 102, Suppl. 1, S3-S9.

157. Shim J-S, Oh K \& Kim HC (2014) Dietary assessment methods in epidemiologic studies. Epidemiol Health 36, e2014009.

158. Centers for Disease Control and Prevention (2016) National Health and Nutrition Survey (NHANES). http:// www.cdc.gov/nchs/nhanes/ (accessed July 2016). 